\title{
Chromosome Studies on the Carex salina Complex (Cyperaceae, Section Cryptocarpae) in Northeastern North America'
}

\author{
Jacques Cayouette ${ }^{2}$ \\ Département de Phytologie and Centre d'Études nordiques, \\ Université Laval, Québec, G1K 7P4, Canada \\ and \\ Pierre Morisset \\ Département de Biologie and Centre d'Études nordiques, \\ Université Laval, Québec, G1K 7P4, Canada
}

Accepted October 9, 1985

The first chromosome studies on Carex were done by Juel (1900) and Stout (1913). The most important ones were done by Heilborn $(1924,1928,1939)$, Tanaka from 1937 to 1941 and Wahl (1940). More recent informations and exhaustive bibliographies are given by Davies (1956), Löve et al. (1957) and Faulkner (1972).

Some cytological features of the genus Carex (and Cyperaceae) are unique. These are 1) the abortion of three of the potential microspores of each tetrad (Fig. 5), 2) a post-reductional meiosis in which the first meiotic division is equational and the second reductional, and 3 ) the long aneuploid series with haploid numbers ranging from $n=6$ to $n=56$, probably due mainly to the unlocalized centromeric activity of the chromosomes.

Chromosome numbers of about 400 of the 2500 species of Carex (according to Nelmes 1952) are recorded by Fedorov (1969); this number could probably reach 500 if an exhaustive updated compilation was made. However, detailed cytological studies of whole sections of Carex are scarce. Extensive works exist only for the Acutae (now Phacocystis) (Faulkner 1972, 1973), Capillares (Löve et al. 1957), Extensae (Davies 1955, Schmid 1982) and Frigidae (Dietrich 1967).

The taxonomically difficult section Cryptocarpae, which includes the Carex salina complex, has not been cytologically studied in extenso. Published chromosome numbers and cytological studies of the Carex salina complex are given in Table 1 . Chromosome numbers and informations from other Cryptocarpae species are found in Löve and Löve (1981), Whitkus (1981), Standley (1983), and in recent indexes (Löve and Löve 1975, Goldblatt 1981).

The Carex salina group belongs to the section Cryptocarpae Tuckerman, also called Temnemis (Raf.) V. Krecz. by Krechetovich (1935) and Egorova (1972). In Europe, section Cryptocarpae is commonly treated as a subsection of the Acutae

1 Based on a thesis submitted by J.C. to the School of Graduate Studies, Laval University, Québec, in partial fulfillment of the requirements for the Ph.D. degree.

. 2 Present address: Biosystematics Research Centre Wm. Saunders Bldg., C.E.F., Ottawa, Ontario, Canada, K1A 0 C6. 
(Kükenthal 1909, Sylvén 1963, Faulkner 1972). Recent workers (Chater 1980) have replaced the sectional epithet Acutae Fries (1835) with Phacocystis Dumortier (1827).

In North America, the Carex salina complex includes four species: $C$. salina Wahl. sensu stricto, C. subspathacea Wormsk., C. recta Boott, and C. ramenskii Komarov (Lepage 1956, 1957a, 1976, Hultén 1942, 1958, 1964). Other authors lump these taxa into one (Boivin 1979) to three (Mackenzie 1935, Scoggan 1978) species.

The present study deals with the Carex salina complex in northeastern North America. Three species are present in that range: C. salina, C. subspathacea and C. recta. C. ramenskii occurs in northwestern North America only (Hultén 1964). Taxonomic treatments differ from one another; Fernald (1950) included four varieties under C. salina, and Gleason (1952) treated C. salina without any infraspecific taxon. His salina according to illustration and description is actually $C$. recta. According to Hultén (1958), C. salina and C. recta are maritime amphiatlantic plants, whereas C. subspathacea is arctic circumpolar (Hultén 1964).

These three species are restricted to salt or brackish marshes along Atlantic, Hudson Bay and James Bay shores. C. subspathacea extends from Arctic coasts (Porsild 1964) to the St. Lawrence River valley, downto Rivière-Ouelle, Kamouraska Co. (Gauthier 1980). C. salina and C. recta have about the same distribution in the northern part of their range. They reach Nain $\left(56^{\circ} 30^{\prime} \mathrm{N}, 61^{\circ} 41^{\prime} \mathrm{W}\right)$ on the Labrador coast and Richmond Gulf in Hudson Bay $\left(56^{\circ} 15^{\prime} \mathrm{N}, 76^{\circ} 17^{\prime} \mathrm{W}\right.$ ) (Dutilly and Lepage 1948, Payette and Lepage 1977). Both occur in the St. Lawrence River valley to Montmagny and Montmorency counties (Gauthier 1980) and the Saguenay River. C. salina reaches northeastern New Brunswick (Bathurst, H. J. Scoggan 11762, CAN, SFS) whereas $C$. recta goes southward to the Boston area, Massachussets (Fernald 1950). According to Lepage $(1956,1966)$, records of $C$. salina from further North should be considered misidentifications or hybrid material.

Generally these three species are markedly distinct on morphological grounds (Mackenzie 1935). C. subspathacea is the smallest of the three (3-30 cm high), C. recta the tallest $(65-90 \mathrm{~cm} \mathrm{high})$, and $C$. salina is intermediate. Some intermediate forms are frequent and generally are of hybrid origin. They represent crosses between species of the Carex salina complex, or between these species and C. paleacea Wahl., another Cryptocarpae, or other species of related sections (Phacocystis, Atratae, Limosae) (Lepage 1956, 1957a, 1957b, 1976, Raymond 1950). An almost exhaustive list of these crosses can be found in Scoggan (1978, p. 425-428). Taxonomical problems are increased by the fact that at least some of these hybrids are quite fertile and that some introgression has probably occurred in some cases (Lepage 1956, Dutilly et al. 1958).

In northwestern Europe, the Carex salina complex includes the same three species as in eastern North America, plus two species that are generally considered of hybrid origin, namely C. halophila F. Nyl. and C. vacillans Drejer (Chater 1980). However, according to Hylander (1966), C. recta is exclusive to North America and all north European "recta" material should be named $C$. vacillans. Hjelmqvist and Nyholm (1947) and Faulkner $(1972,1973)$ stated that European " $C$. recta" is of hy- 
brid origin. Hjelmqvist and Nyholm (1947) and Hylander (1966) thought that European C. salina is also of hybrid origin. Hylander (1966) also suggested that European salina is specifically distinct from the North American one, and that the latter should be called C. lanceata Dewey. Numerous intra- and intersectional hybrids occur in Europe too (Sylvén 1963, Hylander 1966).

A comprehensive taxonomical study of that complex is still to be done. One necessary step in that revision must be an extensive caryological study of all the species and hybrids involved. First detailed chromosome studies were done by Faulkner $(1972,1973)$ on north European C. recta. Studying meiosis of Scottish and Norwegian plants, he could not find any metaphase I with only bivalents. He concluded that European C. recta is of hybrid origin, and that the North American taxon is probably different. For $C$. subspathacea, there exist two meiotic counts and a few mitotic ones, only one mitotic count for $C$. salina, and a recent one for a related

Table 1. Previous chromosome counts of the species of the Carex salina complex

\begin{tabular}{lllll}
\hline \hline Species & \multicolumn{1}{c}{ Country } & \multicolumn{1}{c}{$\begin{array}{c}\text { Diploid } \\
\text { number }\end{array}$} & $\begin{array}{c}\text { Stage } \\
\text { observed }\end{array}$ & \multicolumn{1}{c}{ Reference } \\
\hline Carex subspathacea & Greenland & $78(39 \mathrm{II})$ & PMC & Jørgensen et al. 1958 \\
Wormsk. & Alaska & $c a .78$ & RT & Johnson and Packer 1968 \\
& Iceland & 78 & RT & Löve 1970 \\
& Alaska & $c a .78$ & RT & Packer and McPherson 1973 \\
& USSR & 78 & RT & Yurtsev and Zhukova 1978 \\
& Manitoba & 78 & RT & Löve and Löve 1981 \\
& USSR & 78 & RT & Petrovsky and Zhukova 1983 \\
& Japan? & 80 & PMC & Tanaka 1948 \\
& USSR & 80 & RT & Zhukova and Tikhonova 1971 \\
& USSR & 80 & RT & Zhukova and Petrovsky 1980 \\
& Bear Island & 82 & RT & Engelskjön 1970, 1979 \\
& (Norway) & & & \\
Carex salina Wahl. & Norway & $83 \pm 1$ & RT & Engelskjön 1979 \\
Carex recta Boott & Prince Edward & 84.70 & RT & Löve and Löve 1956 \\
& Island & & RT & Moore and Calder 1964 \\
& Scotland & $73 ?, 74,75 ?$ & PMC & Faulkner 1972 \\
& Norway & $c a .80$ & PMC & Faulkner 1972 \\
& Sweden & $c a .84$ & PMC & Heilborn 1928 \\
& Iceland & 84 & RT & Löve and Löve 1956 \\
Carex halophila & Norway & 78 & RT & Borgen and Elven 1983 \\
F. Nyl. & & & & \\
\hline
\end{tabular}

Norwegian species (or hybrid), C. halophila F. Nyl. (Table 1). The objectives of the present study were to determine the chromosome numbers and describe the meiotic behaviour of the three members of the Carex salina complex in northeastern North America. Other papers (Cayouette and Morisset 1985, 1986) will examine relationships between those three species and other related maritime species such as C. paleacea Wahl., C. aquatilis Wahl., and C. nigra (L.) Reichard, and will also present the cytology of natural hybrids between many of the species involved in that complex. 


\section{Material and methods}

The present study was done mainly along the shores of the St. Lawrence River, where the three species are common. Other southern collections come from the Saguenay Fjord and Chaleur Bay. A few northern Québec specimens were collected

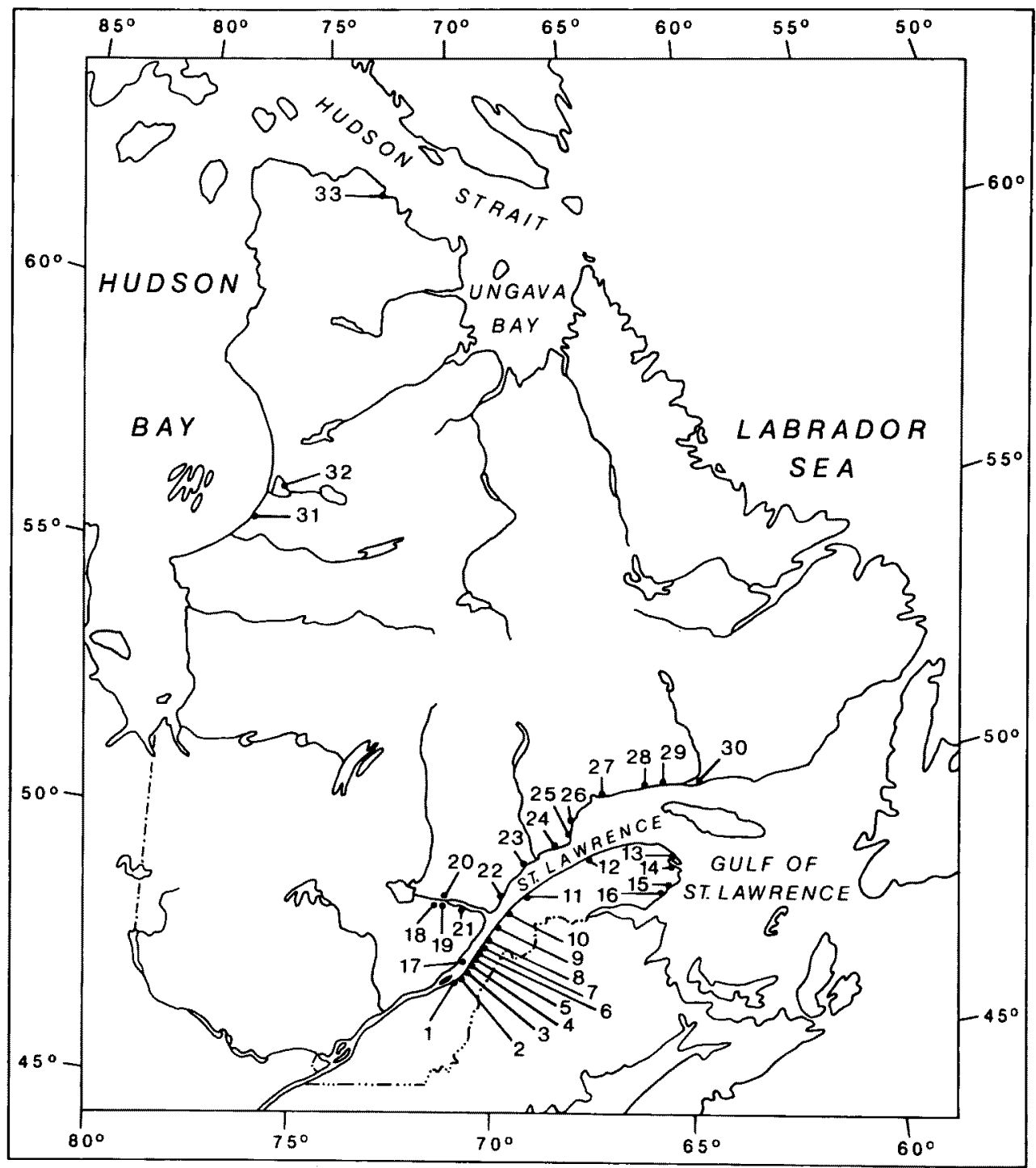

Fig. 1. Distribution of the plants of the Carex salina complex with chromosome counts in the Québec-Labrador Peninsula. (1: Montmagny, 2: Anse à Gilles, 3: L'Islet, 4 : Saint-Jean-Port-Joli, 5: La Pocatière, 6: Rivière-Ouelle, 7: Anse St-Denis, 8: Saint-André, 9: Gros-Cacouna, 10: TroisPistoles, 11: Bic, 12: Capucins, 13: Anse-aux-Griffons, 14: York, 15: Petit-Pabos, 16: Chandler, 17: Île aux Coudres, 18: Rivière-du-Moulin, 19: Rivière Gauthier, 20: Saint-Fulgence, 21: Baie Éternité, 22: Petites-Bergeronnes, 23: Îlets-Jérémie, 24: Baie St-Nicolas, 25: Îlets-Caribou, 26: Rivière-Pentecôte, 27: Maliotenam, 28: Sheldrake, 29: Rivière-St-Jean, 30: Havre-St-Pierre, 31: Manitounuk, 32: Richmond Gulf, 33: Douglas Harbour). 
on the eastern shore of Hudson Bay and on the southern shore of Hudson Strait, Ungava (Fig. 1).

Cytological observations were carried out on living plants collected in the field between 1976 and 1983, and cultivated in the greenhouse and in the experimental garden of the Department of Phytology, Laval University, Sainte-Foy (Québec). Lists of specimens and localities are given in Tables 2-4 and in Fig. 1.

In saltmarshes, one to three living plants from each population investigated were brought back to the greenhouse where they were transplanted into pots in a standard mix soil ( $45 \%$ organic soil, $30 \%$ peat moss, $25 \%$ sand; $\mathrm{pH} 7.0)$. Plants were generally kept under 16 hours of daylight, and temperatures of $15^{\circ}-20^{\circ} \mathrm{C}$. Between November and April, transplanted plants produced many vegetative shoots that were cut down when required. In June all vigorous plants were transplanted into the outdoor experimental garden or kept outside in pots. Garden plots were not artificially watered with salted water even if these Carex species are halophytes. An adequate fertilization was sufficient for good growing conditions. Usually, when plants were transplanted into the garden in June, their first flowering occurred in May of the following year. Transplants of Carex subspathacea were cultivated in pots only, because their relatively superficial roots and rhizomes needed a controlled water supply.

Plants kept outside in pots were brought into the greenhouse at the beginning of November, after some fall frosts. They started flowering 2-4 weeks later. From $65 \%$ to $85 \%$ of the plants flowered in this manner. Non-flowering plants were kept in the greenhouse until April, when they were put in a refrigerated room $\left(4^{\circ} \mathrm{C}\right)$ until July. They were then transferred outside, and almost all of them flowered 2-3 weeks later. This procedure was particularly effective for plants coming from northern latitudes (Hudson Bay and Ungava). The 1980 collections of Carex subspathacea were taken directly from the field into the greenhouse in late October and flowered a few weeks later. The 1983 population of $C$. subspathacea was collected in Richmond Gulf in late July; transplants were kept outside until November and then moved into the greenhouse where they flowered one week later.

Staminate and androgynous spikes were fixed when scales were still pale green. For $C$. subspathacea, the terminal staminate spike had to be fixed before its protrusion from the leaf sheaths. Those of $C$. salina were fixed when they were beginning to grow out of the sheaths, and later on for $C$. recta.

Cytological methods were those of Morisset $(1967,1978)$, with some modifications. Spikes were fixed in Farmer's fixative (glacial acetic acid 1: absolute ethanol 3) for at least 1 hour and up to a maximum of 24 hours. Spikes were sectioned or twisted for a better penetration of the fixative. The material was stained in alcoholic hydrochloric acid-carmine for 18 hours at $60^{\circ} \mathrm{C}$ (Snow 1963). The slides were temporarily sealed with a synthetic rubber gum and could then be kept for a few days in closed plastic bags in a refrigerator.

The slides were made permanent by the following method. The coverslip was carefully lifted with a razor blade while $45 \%$ acetic acid was poured under the corner which was being lifted. In this way the cells were neither freed nor rolled up through acetic acid displacement due to capillary pressure. The slide and the coverlip were 
then placed in a mixture of glacial acetic and absolute ethanol (1:3) for about 30 seconds. They were then transferred to two consecutive baths of absolute ethanol for at least 1 minute before being remounted in Euparal.

Usually 2-3 anthers from the same flower were squashed on the same slide. Up to 20-25 chromosome counts from each slide were made in metaphase I, first pollen grain mitosis, and once in a pre-meiotic mitosis (Fig. 21). Photographs of the best chromosome preparations were usually taken in phase contrast with a Carl Zeiss Photomicroscope using Ilford Pan-F135 film. Voucher specimens are deposited in the Laval University Herbarium (QFA) and slides at the laboratory of P. Morisset, Department of Biology, Laval University.

\section{Results}

\section{Synchronization of meiotic stages}

Within a given staminate spike, meiosis always proceeds from the bottom to the apex. Upper spikes generally mature prior to the lower ones. On small staminate spikes of $C$. subspathacea and C. salina, meiosis is usually synchronized within and between anthers of the same level. Younger stages are situated just above that level and older stages just below. On long spikes of $C$. recta (and some of $C$. salina), the synchronization of meiotic stages occurs on a longer part of the spike. For example, on a $6 \mathrm{~cm}$ long staminate spike of $C$. recta, one could observe at the very bottom the end of first pollen mitosis, in the middle (for $2-3 \mathrm{~cm}$ of length) prophases and metaphases of first pollen mitosis, and meiotic stages (from metaphase I to telophase II) in anthers at the tip of the spike.

\section{Meiotic stages and first pollen mitosis}

Diakinesis. Non-bivalent associations were present in all the studied material of C. salina and C. recta, and in some cytotypes of C. subspathacea, and their correct identification was essential for an accurate interpretation of metaphase plates. We could not distinguish easily univalents, bivalents, and multivalents at diakinesis (Fig. 9), and therefore only the number of meiotic associations could be counted at that stage. It was observed that nucleolar chromosomes are frequently of large size (large bivalent or quadrivalent).

Metaphase I. At early metaphase I, bivalents are readily recognized by their dumb-bell shape, but it was not always easy to separate quadrivalents with a rounded shape from large bivalents (Fig. 23). Univalents also have a rounded shape (Fig. 23) and can sometimes look like small bivalents. Therefore their size was not always reliable as a distinguishing character. Trivalents form straight or curved chains (Figs. 11, 23), or sometimes have a "frying-pan" shape as described by Faulkner (1972). Chain trivalents were easily enough recognizable but frying-pan ones could occasionally look like heteromorphic bivalents (Fig. 27).

Late metaphase I and early anaphase I were the best stages for accurate identification of univalents and multivalents. Univalents are then small spherical bodies (Figs. 11-14), or narrow structures when observed at the beginning of their division. It has long been known that univalents in Cyperaceae usually divide at first meiotic 
division (Heilborn 1928, 1939, Wahl 1940, Tanaka 1941a). Bivalents showed a characteristic quadrangular shape with one chromatid in each corner (Figs. 14, 25) or a long dumb-bell-like shape (Figs. 10, 14, 26). Larger bivalents were easily recognized at this stage (Figs. 10,22). Chain trivalents, both homomorphic and heteromorphic, were best distinguished also at this stage (Fig. 14). Frying-pan or triangular trivalents looked like bivalents with one univalent attached on one side (Fig. 10). Faulkner (1972) interpreted these as homomorphic. Ring quadrivalents were best seen at these stages (Figs. 11, 12, 25). Large spherical structures were also interpretated as ring quadrivalents. Chain quadrivalents were seen more rarely; they were commonly homomorphic (Fig. 8), and some heteromorphic ones were infrequent. Another infrequent type of quadrivalent appeared like two joined II's (Fig. 27). A pentavalent was seen only twice, in one anther of $C$. recta. It appeared like a quadrivalent with a univalent attached on one side (Fig. 26).

Metaphase II. Chromosome counts of Carex were made on metaphase II by some authors (Heilborn 1924, Wahl 1940, Tanaka 1940a, 1940b, 1940c, 194la, 1941b, Schmid 1982). Others, like Faulkner (1972), failed to make accurate counts at that stage, mainly because the differing orientations of the two metaphase plates did not permit a good identification with squash methods. We also failed to make chromosome counts from metaphase II plates. Multivalents were sometimes seen at metaphase II (Fig. 15), indicating that the first meiotic division is equational.

Anaphase II. When univalents and multivalents are present, there is some disturbance at late anaphase II. This was observed by several earlier authors (Tanaka 1940a, 1940b, 1941b, Wahl 1940, Faulkner 1972). Univalents, which had already divided at anaphase I, frequently lagged at this stage (Fig. 17). Some larger chromosomes may have been laggards too (Fig. 16). When anaphase II was completed, they had reached one of the two poles (Fig. 18). This was observed and demonstrated by Strandhede (1965a) on Eleocharis. Trivalents separated at anaphase II with uneven numbers migrating towards each pole. Other disturbances such as bridges were not seen in the Carex salina complex.

First pollen mitosis. In Carex, like in all Cyperaceae, only one microspore of the tetrad completes the pollen mitosis, while the three remaining ones degenerate. Haploid chromosome counts are easily made in late prophase and metaphase of that first pollen mitosis (Figs. 5, 19, 20, 28, 29). When univalents and multivalents are present at first metaphase, the number of haploid chromosomes can vary between pollen grains. This variation is slight when there is only one univalent or trivalent, but the range of numbers in pollen grains is much greater when multivalents are more numerous.

Chromosome size. Chromosomes were not readily classified in size classes. Within the genus as a whole, chromosome sizes diminish as chromosome numbers increase. Working with species having low chromosome numbers, some authors could classify the latter in three (or four) size classes: small, medium and large (plus giant) (Heilborn 1924, 1928, 1939, Tanaka 1939a, 1939b, 1940a, 1949, Löve et al. 1957). When the numbers are higher, such as in section Phacocystis, chromosomes are much more uniform in size and only 1-3 larger bivalents can be singled out (Faulkner 1972). The same situation occurred in the Carex salina complex. Chro- 


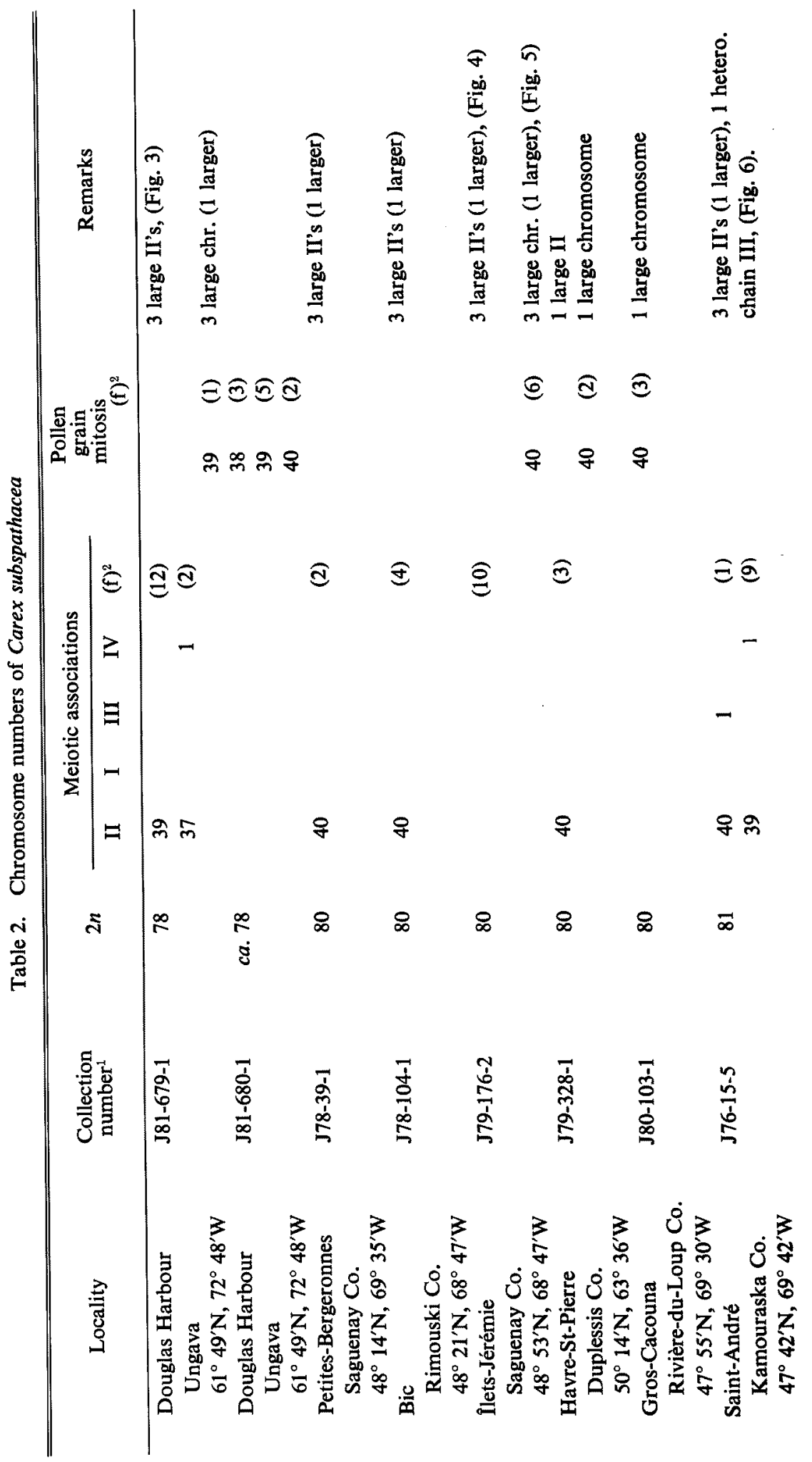




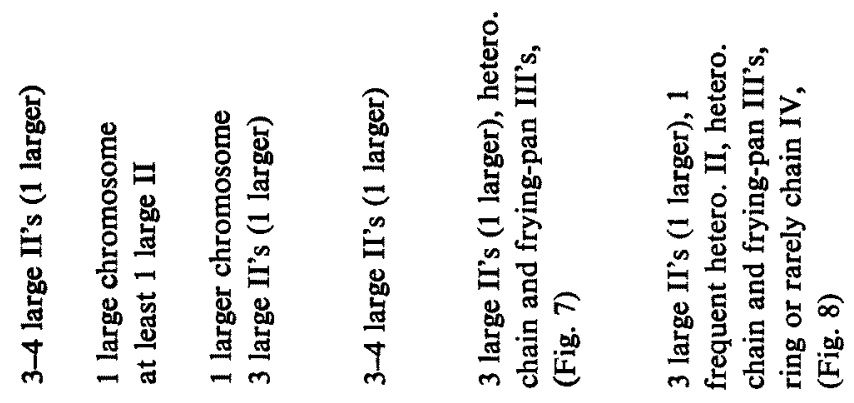

$\Xi \approx$

₹

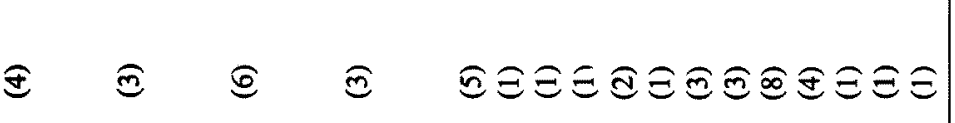
$\rightarrow-4 \rightarrow-7-4-4$

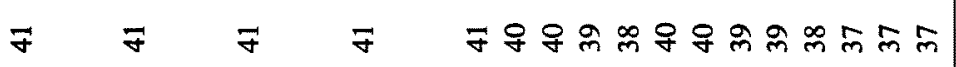

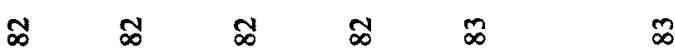

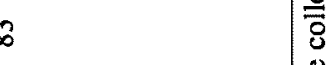

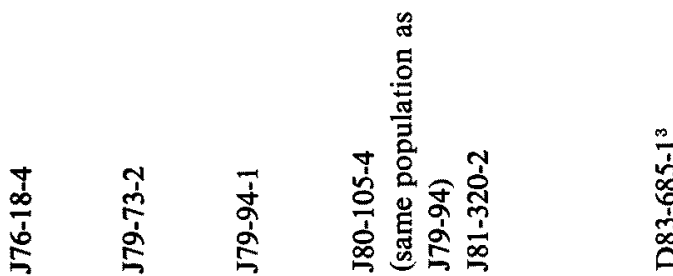

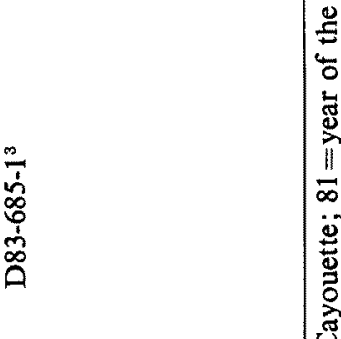

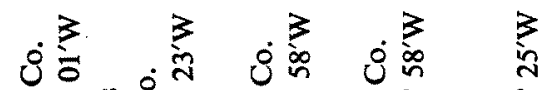

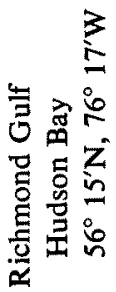


mosome were not readily classifiable in size classes, but some large bivalents were clearly seen either in metaphase I (Figs. 3, 4), or in metaphase of first pollen mitosis (Figs. 5, 20). At least one pair of these larger chromosomes were the nucleolar one, as could be seen in diakinesis (Fig. 9), interphase and prophase of first pollen mitosis (Figs. 19, 28).

\section{Carex subspathacea}

Up to 121 chromosomes counts at metaphàse I and first pollen mitosis were made on 14 plants coming from 12 different localities, giving five different chromosome numbers: $2 \mathrm{n}=78,80,81,82,83$ (Table 2): Four of these numbers were known

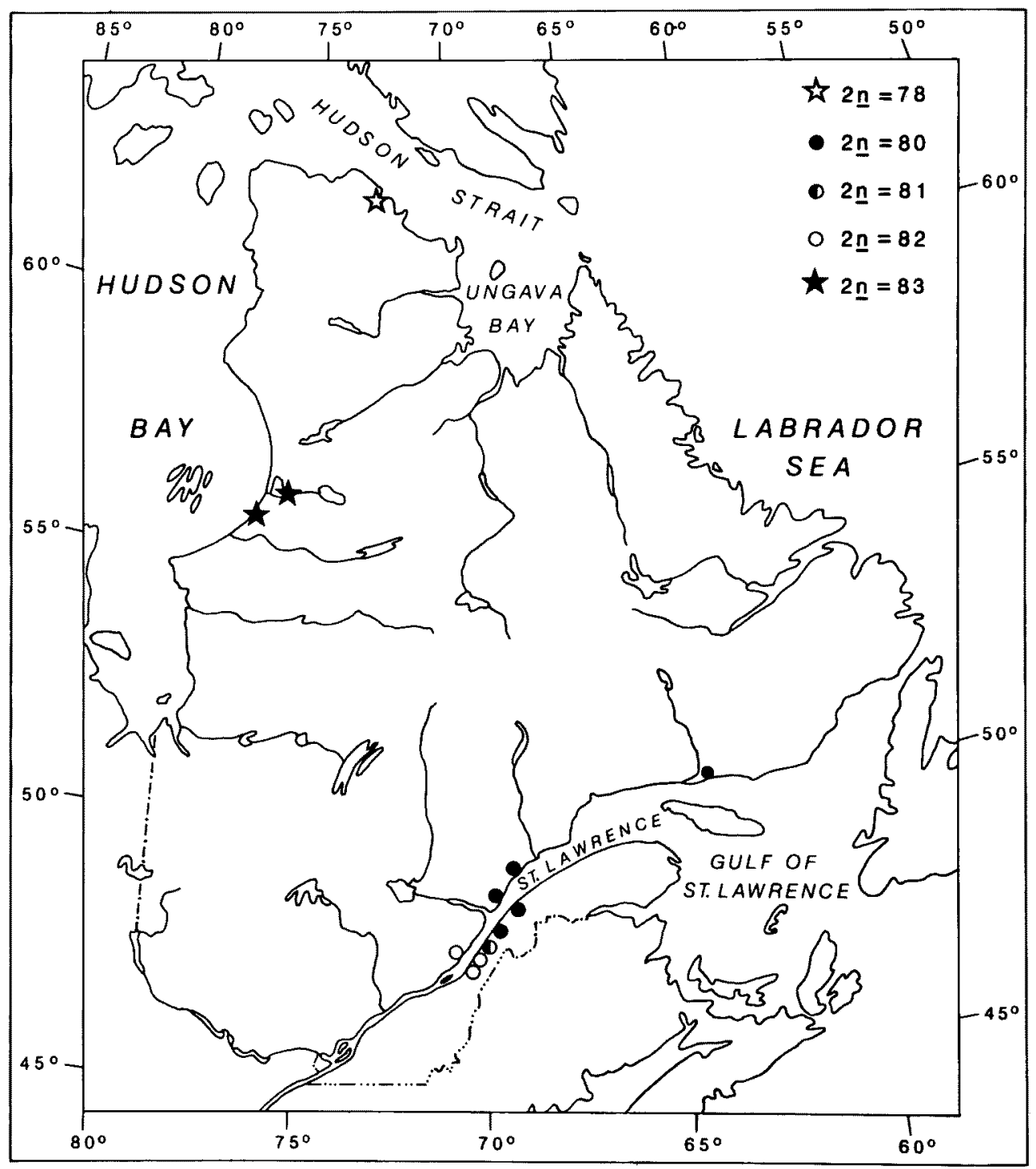

Fig. 2. Distribution of the five cytotypes of Carex subspathacea in the Quebec-Labrador Peninsula. 
from previous workers (Table 1 ), the remaining one, $2 \mathrm{n}=81$ being new for $C$. subspathacea. Among published chromosome counts, only those of Jørgensen et al. (1958) and Tanaka (1948) were meiotic counts. Others were root mitosis counts and some of them were approximate.

These five cytotypes had the same number of larger bivalents. At metaphase I, there were three larger bivalents, two being slightly smaller than the largest one (Figs. 3, 4, 6, 7). These three larger chromosomes were also seen at metaphase of first pollen mitosis (Fig. 5). On a metaphase plate of C. subspathacea with $\mathrm{n}=39$ II from Greenland, Jørgensen et al. (1958) also pointed out three larger bivalents.

Our data demonstrate that there are at least two euploid cytotypes for $C$. subspathace $(2 \mathrm{n}=80$ and 82$)$, that is cytotypes with a perfectly regular meiosis. One plant collected in the Ungava Peninsula (Fig. 2) is quasi euploid with $2 n=78$ (Table 2, Fig. 2). The other two euploid cytotypes were encountered on plants of the St. Lawrence River valley. Five plants from five localities had $2 n=80$, and four plants from three localities had $2 n=82$ (Table 2). Two aneuploid numbers were found $(2 n=81,83)$. The plant with $2 n=81$ was collected in the St. Lawrence River valley (Fig. 2). Meiosis was not very much disturbed, with the presence of one univalent or one trivalent (mostly heteromorphic) at metaphase I (Fig. 6). The two other aneuploid plants $(2 n=83)$ came from Hudson Bay shores (Fig. 2). Meiosis in these plants was the most disturbed of all the cytotypes of C. subspathacea examined. Ten different combinations were recorded (Table 2). At metaphase I, most of the chromosomes were bivalents (37-41); univalents and trivalents were less frequent (1-3), and a chain (Fig. 8) or ring quadrivalent was commonly observed. A frying-pan trivalent (Fig. 7) and heteromorphic bivalents were occasionally seen.

The different cytotypes of $C$. subspathacea did not have the same geographical distribution in Québec (Fig. 2). Only three accurate chromosome counts were made on plants from northern latitudes $(2 \mathrm{n}=78,83)$ and they were different from those of the St. Lawrence River $(2 n=80,81$ and 82$)$. The latter three numbers showed a distinct geographical pattern within the St. Lawrence River valley. All four counts of $2 \mathrm{n}=82$ came from a limited area at the southern limit of the species in Québec (Gauthier 1980): Île aux Coudres, on the north shore of the St. Lawrence River, Rivière-Ouelle and Anse St-Denis on the south shore. The $2 n=80$ cytotype was distributed further east and the only plant with $2 \mathrm{n}=81$ was geographically intermediate (Fig. 2). Unfortunately our data are too scanty to draw a complete geographical pattern of the cytotypes of $C$. subspathacea in northeastern North America.

Other chromosome counts from elsewhere are not abundant enough to show any worldwide geographical pattern in the distribution of the cytotypes (Table 1). The only clear tendency is for plants with $2 n=78$ to come from northern or arctic latitudes (Greenland, Alaska, Iceland, northeastern USSR, northeastern Manitoba, and northernmost Québec).

On morphological grounds, plants coming from the St. Lawrence River valley are remarkably uniform, and there is no apparent difference between cytotypes. Northern Québec collections show slight differences from the southern ones. Generally, collections from southern latitudes are smaller, have narrow and involute 


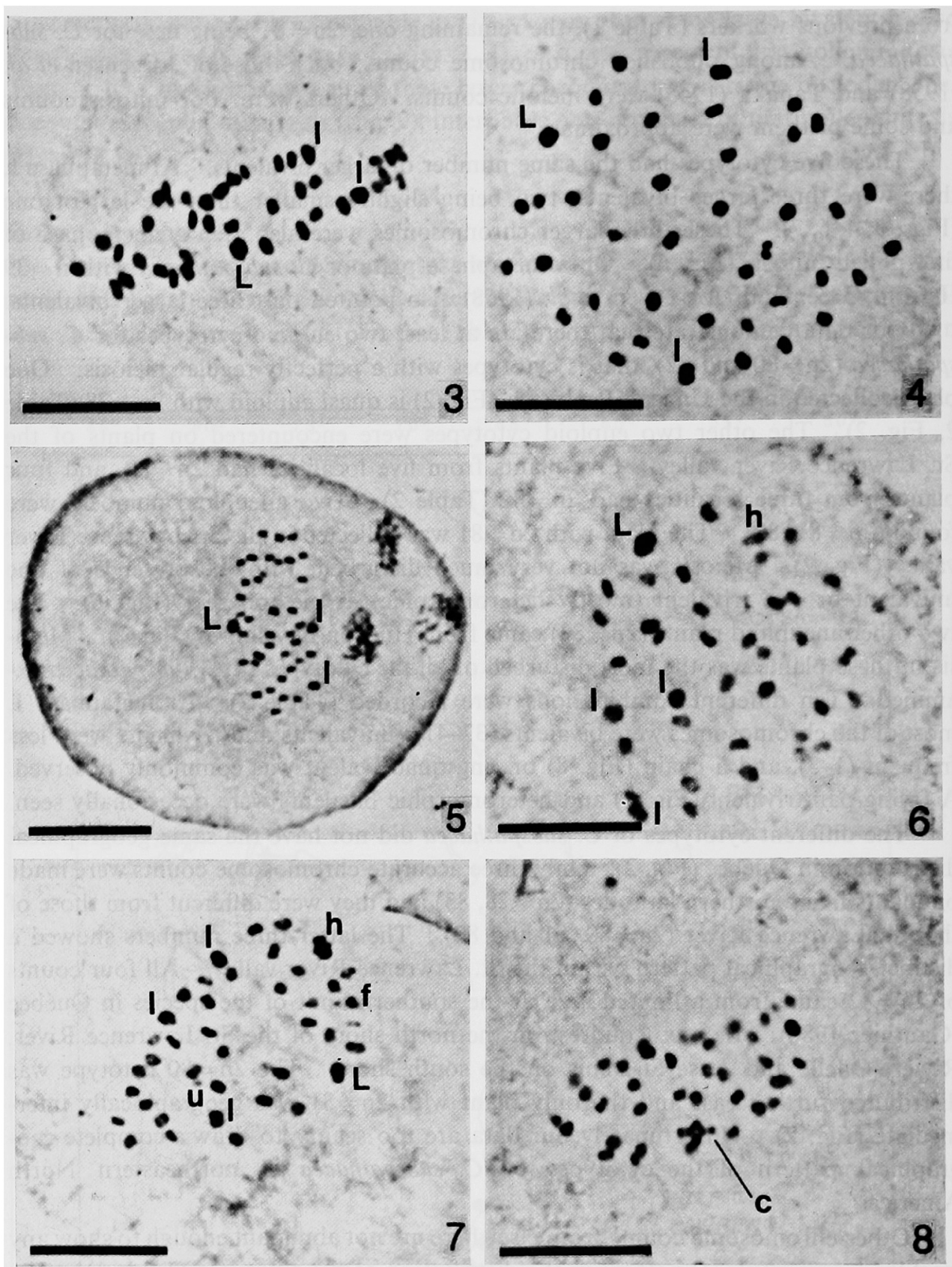

Figs. 3-8. Meiosis and first pollen mitosis in Carex subspathacea. 3, early metaphase I in no. J81-679-1 (Douglas Harbour) $2 \mathrm{n}=78$ (39II). There are three large bivalents (1), one being the largest (L). 4, metaphase I in no. J79-176-2 (Îlets-Jérémie) $2 \mathrm{n}=80$ (40II). There are three large bivalents (1), one being the largest (L). 5, metaphase of first pollen mitosis in no. J79-176-2 (îletsJérémie) $n=40$. There are three large chromosomes (1), one being the largest (L). The three degenerating nuclei are seen at right. 6, metaphase I in no. J76-15-5 (Saint-André) $2 \mathrm{n}=81$ (39II+ 1III). The trivalent is a heteromorphic chain (h.) There are four large bivalents (1), one being the largest (L). 7, metaphase I in no. J81-320-2 (Manitounuk) $2 \mathrm{n}=83$ (38II + 1I + 2III). One trivalent is a heteromorphic chain (h), the other one is a frying-pan (f). There are four large bivalents (1). one is larger $(\mathrm{L})$. The univalent is a small body $(\mathrm{u})$. 8, metaphase $\mathrm{I}$ in no. D83-685-1 (Richmond Gulf) $2 n=83$ (38II + 1III + 1IV). The homomorphic chain quadrivalent is clearly visible (c). Bar scales $=10 \mu \mathrm{m}$. 
leaves, one staminate spike (no androgynous one), and, pale, short acute pistillate scales. Northern Québec C. subspathacea plants are slightly taller, have less narrow and less involute leaves, 1-2 staminate spikes, often an androgynous one, and have somewhat longer and darker pistillate scales. However, achenes of all these cytotypes are quite alike, with the same shape, the same dull surface, and the absence or nearly complete absence of invagination. Northern latitudes forms have sometimes been classified as intermediate between $C$. salina and $C$. subspathacea (Polunin $1940,1948)$, but Lepage $(1956,1966)$ stated that some of these plants were hybrids.

\section{Carex salina}

Up to 256 chromosome counts at metaphase I and first pollen mitosis were made on 22 plants from 16 localities revealing three aneuploid numbers for $C$. salina: $2 \mathbf{n}=77,78$ and 79 (Table 3 ). These numbers have not been reported before from $C$. salina, the only earlier count for this species being the mitotic number of $2 n=84$ from an Icelandic plant (Löve and Löve 1956) (Table 1).

The $2 n=77$ number was found on 11 plants from 10 different localities, $2 n=78$ on 5 plants from 4 localities, and $2 n=79$ on 6 plants from 5 localities (Table 3 ). Moreover, counts made at first pollen mitosis of seven other plants gave an approximate haploid count for these plants (Table 3).

None of these three cytotypes behave as a regular euploid. At metaphase I, there was always one or a few non-bivalent associations. Most of the meiotic associations were bivalents (28-36). Univalents (0-8), trivalents (0-5), and quadrivalents (0-2) were of frequent occurrence.

Bivalents varied in size, and we could only recognize two or three which were larger, one or two being slightly smaller than the largest one (Figs. 10, 11). These larger chromosomes were seen again at first pollen mitosis (Fig. 20), and were commonly associated with the nucleole (Fig. 19). An heteromorphic bivalent was seen rather frequently (Figs. 11, 14).

Univalents (Figs. 10-14) rarely numbered more than two per cell (Fig. 12). Fragments such as those mentioned by Faulkner (1972) were not seen. Every small meiotic unit encountered in the present material proved to be univalent. Univalents were seen lagging in late anaphase II (Fig. 17); sometimes larger laggers (certainly not univalents) could also be observed at that stage (Fig. 16).

Trivalents were of four different morphological types. Heteromorphic chain trivalents seemed to be the most frequent (Figs. 10,11, 12, 14); homomorphic chain trivalents (Figs. 11, 14) and frying-pan trivalents (Figs. 10, 12, 14) were frequent too. Triangular trivalents, perhaps not different from the frying-pan ones, were rarely seen (Fig. 13).

Two types of quadrivalents were encountered, but ring quadrivalents, as they clearly appeared in late metaphase I (Figs. 11, 12) and in metaphase II (Fig. 15) were by far more frequent than chain quadrivalents. Chain quadrivalents were seen in the $2 n=77$ and 79 cytotypes only.

The occurrence of different meiotic associations at metaphase I within an individual plant was frequent. For instance on the plant no. J78-16-35 from Anse St-Denis $(2 n=79), 14$ different meiotic combinations were seen on 20 cells examined 


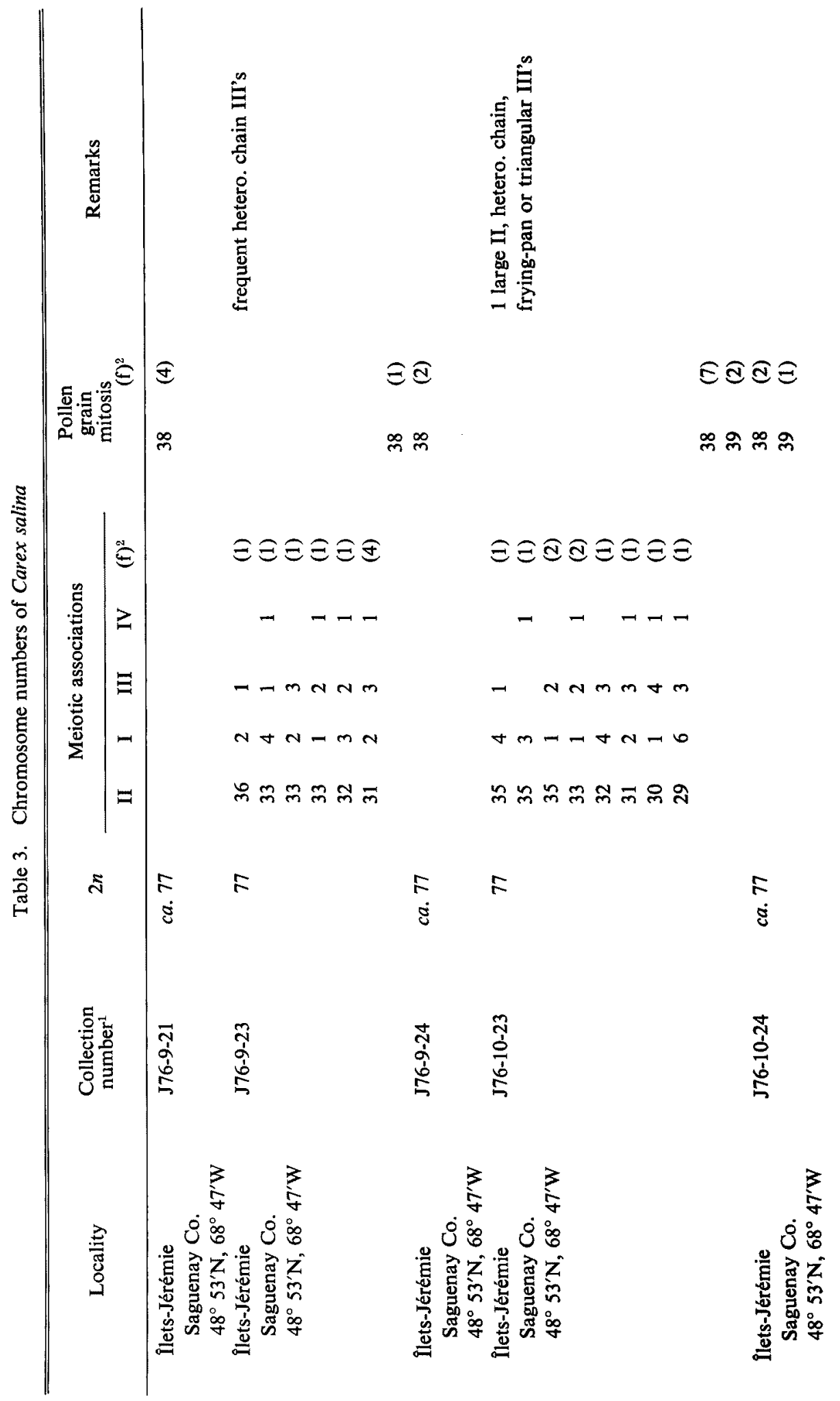


苟

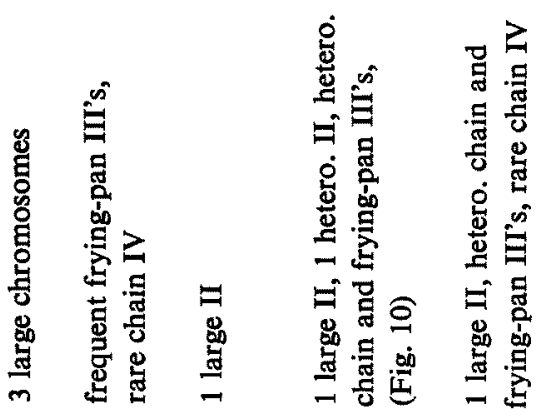

E.

$\Xi \overparen{d}$

$\widehat{\Xi} \widehat{\mathbb{S}}$

nิ

융

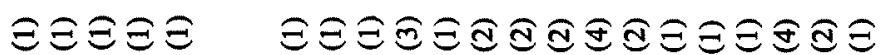

$\widehat{\Xi} \widehat{\Xi}$
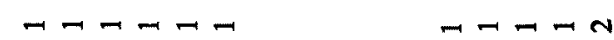

$-n m+t$

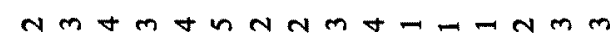

N $\mathrm{N}$

$n m n \rightarrow m$

$-4 \sin 4 m n n-4 n+74 n$

$m--$

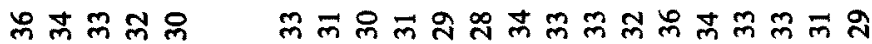

$m m m$

$\Sigma$

$=F$

$\vDash$

$E$

$\frac{\vec{b}}{3}$

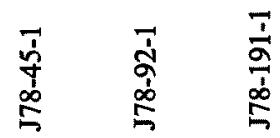

$T$
$\infty$
$\infty$
$\vdots$
$\vdots$
5

$\frac{2}{\frac{1}{1}}$
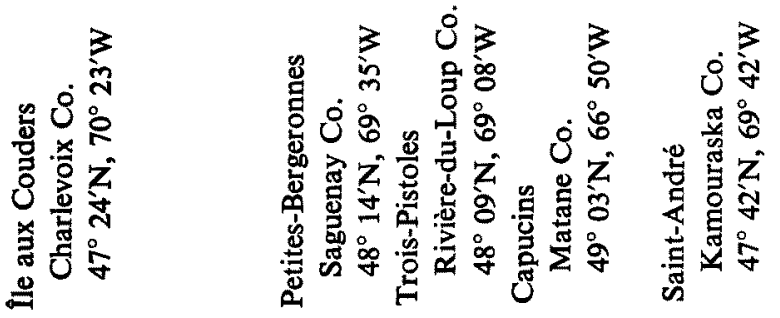

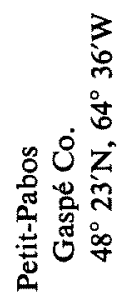




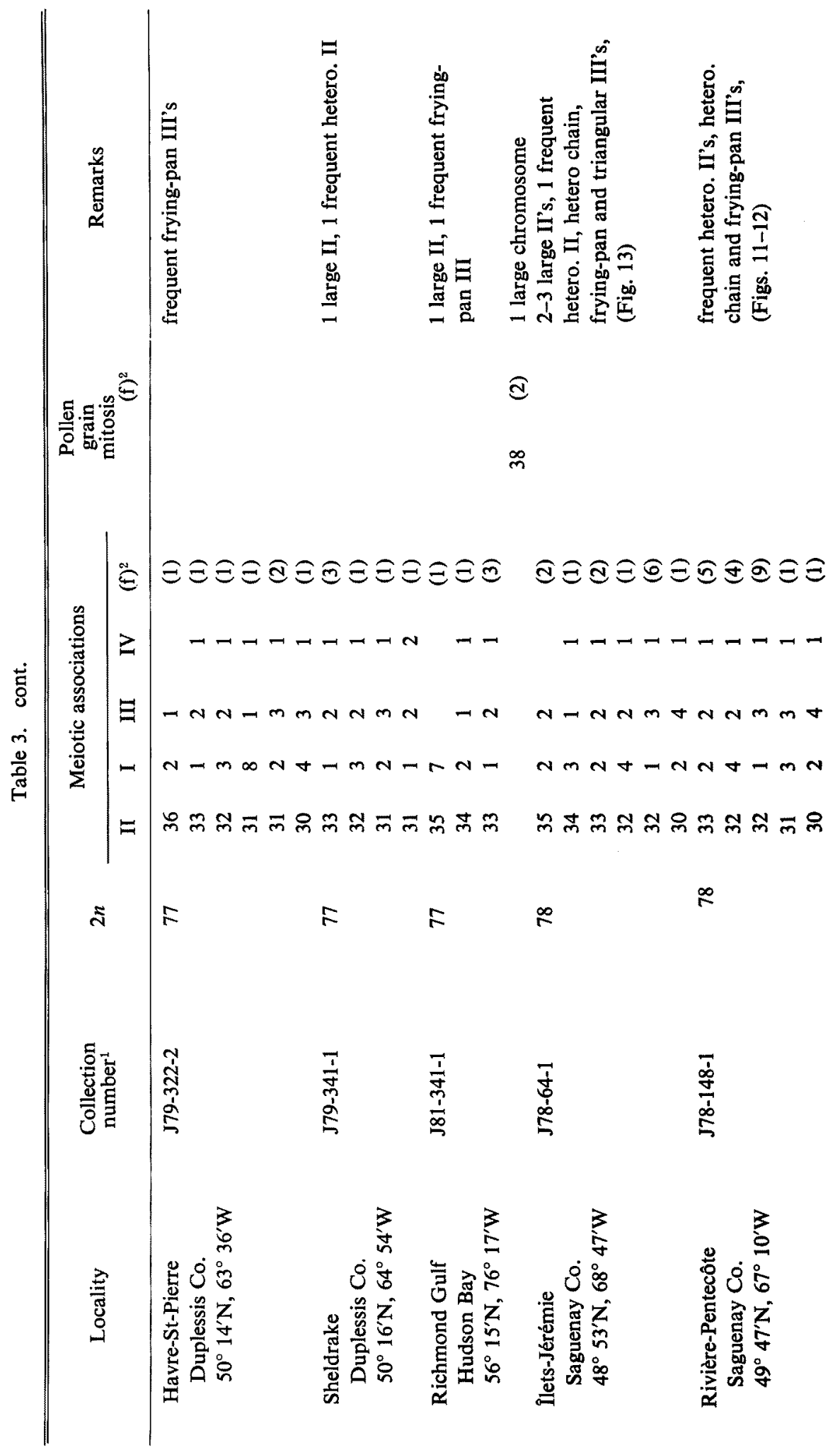




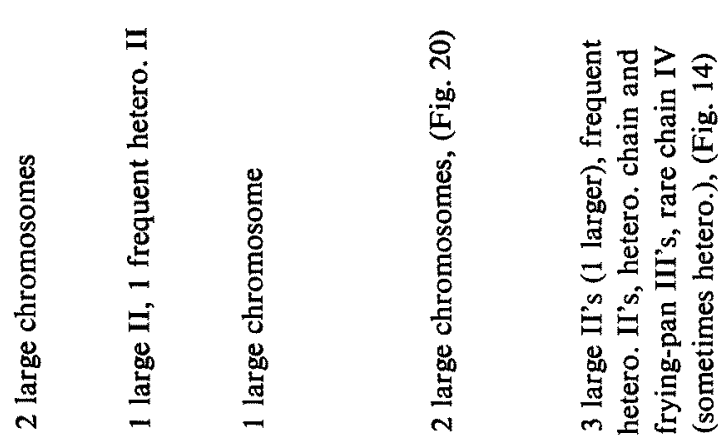

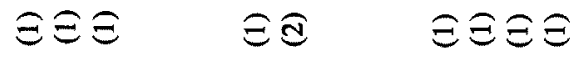

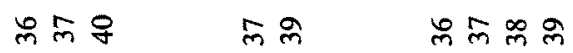

$\Xi \Xi \Xi \Xi$

$\widehat{0}$

$\nexists$

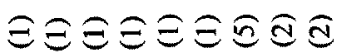

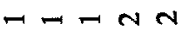

$-m m \forall$

Nm

$-4 m n d n m m a$

$-m-m$

$N-1$

$A-\theta m-\operatorname{nat}$

m

$m$ กิ

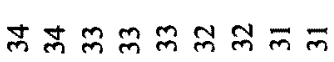

$\stackrel{\infty}{\sim}$

$\stackrel{\infty}{\circ} \stackrel{\infty}{9}$

9

$\frac{a}{a}$

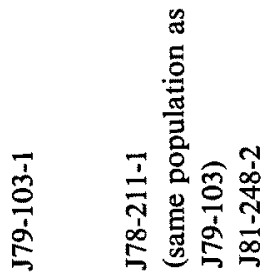

$m$
$b$
$\frac{1}{1}$
0
5

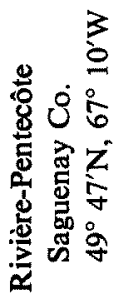

ن年
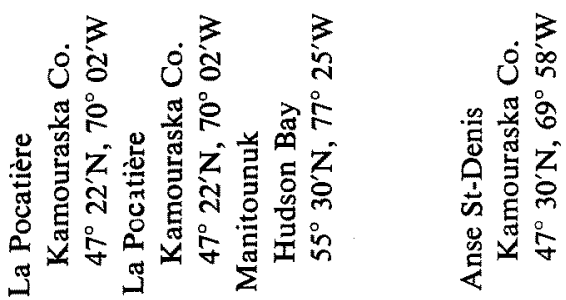


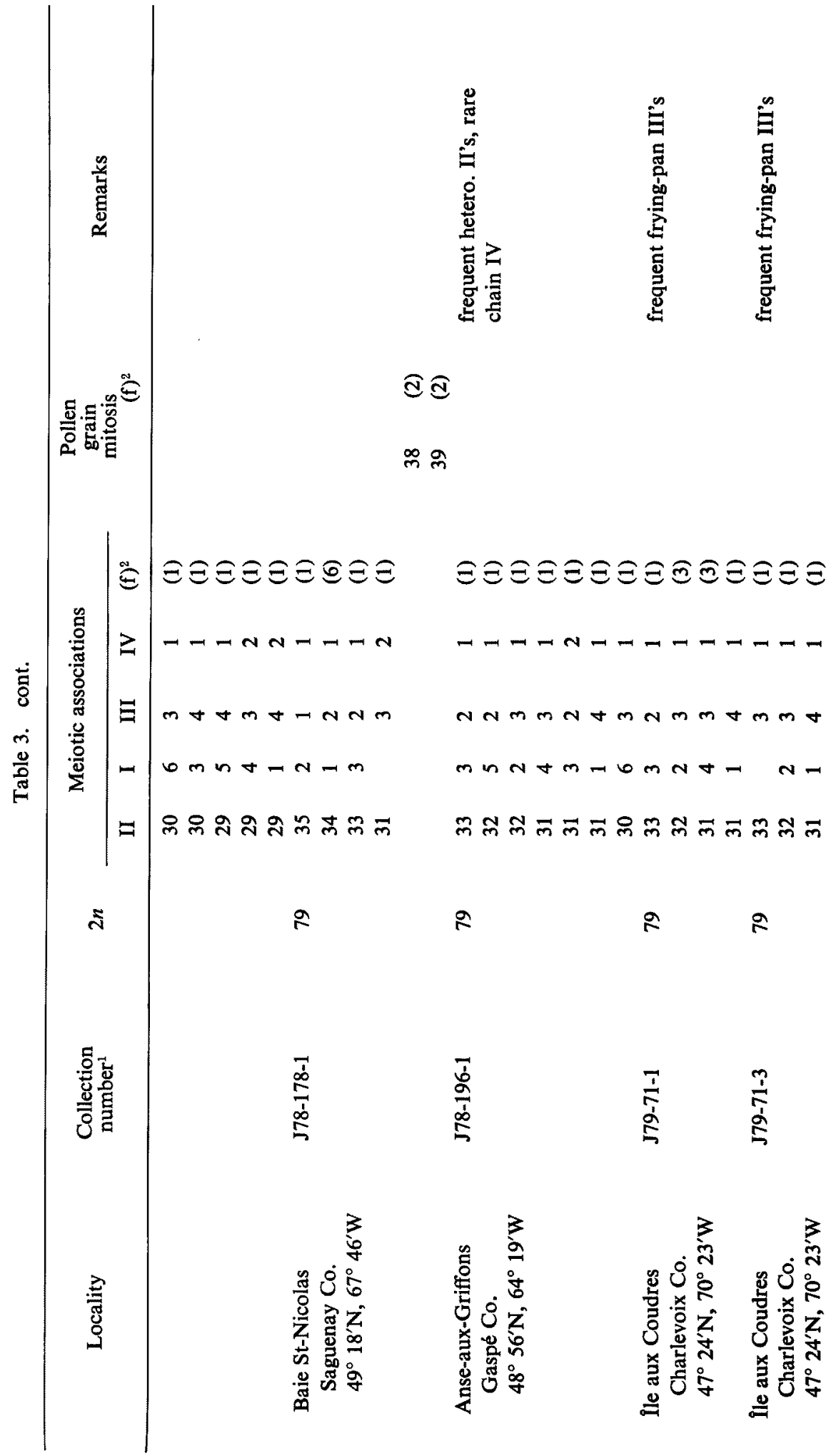


惫

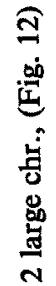

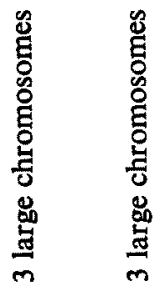

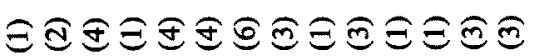

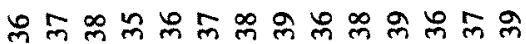

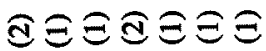

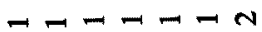

$\operatorname{Hnmmtm}$

nem $n A \rightarrow$

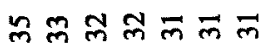

2

$\frac{9}{1}$

$\begin{array}{ll}\frac{9}{1} & \frac{9}{1} \\ \frac{8}{5} & 8\end{array}$

홍

$\stackrel{7}{\mathfrak{d}}$

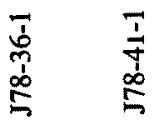
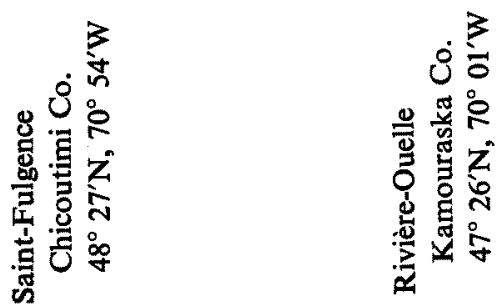

ن 娄密

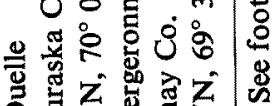

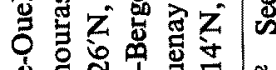


(Table 3). Two examples of the combinations in plant no. J78-148-1 from RivièrePentecôte $(2 n=78)$ are illustrated on Figs. 11 and 12.

The mean numbers of bivalents and univalents calculated from Table 3 were quite uniform among the three cytotypes, but the frequency of trivalents and especially quadrivalents increased with the number of chromosomes. For example, a quadrivalent was observed in $97 \%$ of cells in the $2 n=79$ cytotype, but the frequency was $66 \%$ for $2 n=77$.

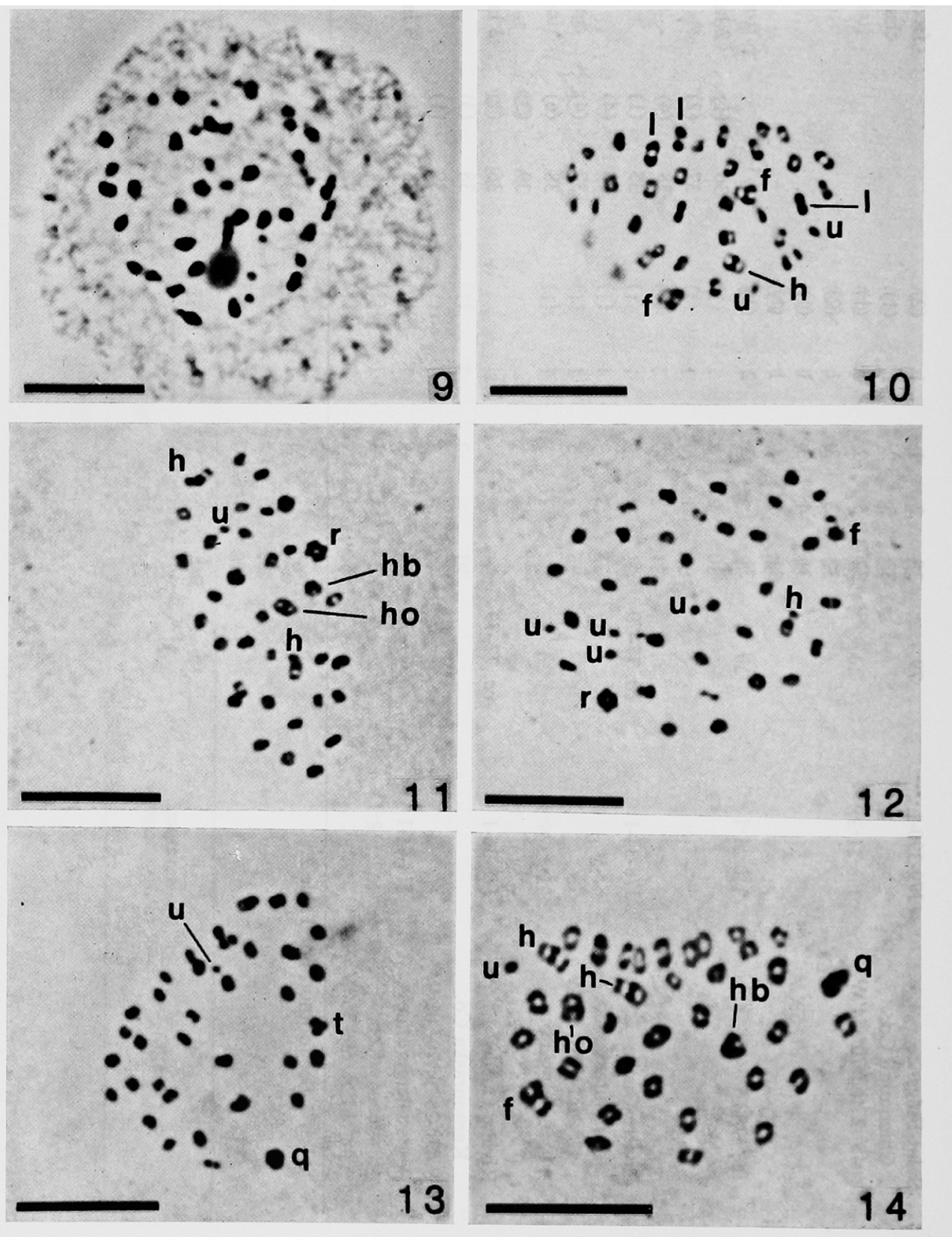


The three cytotypes did not show any allopatrical distribution in the range studied. All three were present in the St. Lawrence River valley, and two in the Hudson Bay area.

There were no apparent morphological differences between the three cytotypes. Plants of the three groups showed extremes of variation. For example, two plants with $2 \mathrm{n}=78$ ( $J 78-64-1$ : Îlets-Jérémie, and J79-103-1: La Pocatière) were respectively short, with acute to short aristate pistillate scales, and tall, with long scabrous-awned pistillate scales. However, such differences were slightly attenuated when these plants were cultivated in an experimental garden with uniform growing conditions.

\section{Carex recta}

Chromosome counts were made on 25 plants collected in 18 different localities from southern Québec (St. Lawrence River, Saguenay River, and Chaleur Bay) and Hudson Bay. A total of 278 counts on metaphase I and first pollen mitosis revealed that at least three aneuploid cytotypes were present in the study area, $2 n=73$ for 20 plants, $2 n=75$ for 3 plants and $2 n=76$ for two plants (Table 4). All these numbers except $2 n=76$ were recorded by Faulkner (1972) from northern Scottish plants, but they were approximate counts. The only accurate number reported by Faulkner (1972) was $2 \mathrm{n}=74$, again from northern Scotland. In North America, the only published chromosome number for $C$. recta is a root-tip mitosis count of $2 \mathrm{n}=c a$. 70 from Prince Edward Island, Canada (Moore and Calder 1964). As stated by earlier Carex workers (Faulkner 1972), root-tip counts of Carex may be divergent from cell to cell and are not always accurate. Other published counts reported from Scandinavia $(2 \mathrm{n}=c a .80$ and $2 \mathrm{n}=84$; Table 1$)$ are much higher.

The three studied cytotypes of $C$. recta had the following characteristics. Metaphase I always showed at least one non-bivalent association. Bivalents, as in $C$. salina, were the most numerous (28-37). Univalents (0-7), trivalents (0-4), and quadrivalents $(0-2)$ were frequent, and a pentavalent was seen twice. The most

Figs. 9-14. Meiosis in Carex salina. 9, diakinesis in no. J78-16-36 (Anse St-Denis) 2n=ca. 79. Distinction between bivalents and non-bivalents is not accurate at this stage. One larger chromosome (bivalent?) is associated with the nucleole. 10, late metaphase $I$ in no. $J 78-191-I$ (Capucins) $2 n=77(33 I I+2 I+3 I I I)$. Bivalents adopt the square shape or are dumb-bell-like; two or three are larger than the others (1). One trivalent is a heteromorphic chain with the largest chromosome in the middle of the chain (h); the other two are the frying-pan type and look like bivalents with one univalent attached on one side (f). The two univalents are very small (u). 11, late metaphase I in no. $J 78-148-1$ (Rivière-Pentecôte) $2 \mathrm{n}=78(32 \mathrm{II}+1 \mathrm{I}+3 \mathrm{III}+1 \mathrm{IV})$. The ring quadrivalent is clearly visible (r). One chain trivalent seems homomorphic (ho), the other two are heteromorphic and form curved chains $(\mathrm{h})$. One bivalent is heteromorphic (hb). 12, late metaphase I in no. J78-148-1 (Rivière-Pentecôte) $2 \mathrm{n}=78(32 \mathrm{II}+4 \mathrm{I}+2 \mathrm{III}+1 \mathrm{IV})$. Univalents can be distinguished by their small rounded shape (u). One ring quadrivalent is visible (r). One trivalent is a heteromorphic chain (h), the other is of frying-pan type (f). 13, metaphase I in no. J78-64-1 (Îlets-Jérémie) $2 \mathrm{n}=78$ (32II $+1 \mathrm{I}+3 \mathrm{III}+1 \mathrm{IV})$. One of the trivalents has a triangular shape $(t)$. The quadrivalent appears as a massive rounded body (q). 14, late metaphase I in no. J78-16-35 (Anse St-Denis) $2 n=79$ $(31 I I+1 I+4 I I I+1 I V)$. Bivalents adopt square or rectangular shapes. One larger bivalent is heteromorphic (hb). Two trivalents are heteromorphic chains (h), one seems homomorphic (ho), and the remaining one is a frying-pan ( $f$ ). The quadrivalent has a heteromorphic shape (q). The univalent is a small body (u). Bar scales $=10 \mu \mathrm{m}$. 
simple combinations were seen on the $2 n=73$ cytotype $(36 I I+I, 35 I I+I I I)$ (Table 4).

Chromosome morphology was somewhat similar to that of $C$. salina. As seen in metaphase I and early anaphase I, bivalents were not readily classified in size classes, but at least one larger bivalent was always observed (Fig. 23). Faulkner (1972) reported such a large bivalent from Scottish material. We frequently observed up to three larger bivalents (Fig. 22) on plants coming from the southernmost distribution of the species in the St. Lawrence River valley (Montmagny, L'Anse-àGilles, L'Islet, Saint-Jean-Port-Joli), and also on plants from the upper Saguenay area (Saint-Fulgence, Rivière-du-Moulin). These large chromosomes, that could also occur as quadrivalents were frequently associated with the nucleole when seen at diakinesis, interphase and late prophase of the first pollen mitosis (Fig. 28). Heteromorphic bivalents were frequently seen.

Like in C. salina, all small rounded units were always interpreted as univalents (Figs. 22, 23, 27); no fragments were detected. Univalents were seen lagging at late anaphase II, as already observed by Faulkner (1972) in C. recta.

Trivalents were of three morphological types: heteromorphic chain trivalents (Figs. 22-25, 27), homomorphic chain trivalent and frying-pan trivalents (Figs. 22, 24, 25, 27). Quadrivalents showed a rounded spherical pattern (Figs. 23, 24, 27) or the characteristic ring appearance as seen in early anaphase I (Fig. 25). Chain quadrivalents were seen in the $2 n=76$ cytotype only. A pentavalent was clearly observed twice in one plant $(2 \mathrm{n}=75$, from Gros-Cacouna, no. J79-127A-1). It looked like a quadrivalent with a univalent attached on one side (Fig. 26). This kind of association had not yet been positively recorded, neither for $C$. recta nor for any other Cryptocarpae and Phacocystis Tanaka (1940a) observed pentavalents of this kind in Carex siderosticta Hance.

First pollen mitosis counts gave varying numbers for each plant. These numbers varied from 34 to 39 chromosomes, with highest frequencies from 35 to 37 (Table 4; Fig. 28). In one case we observed a non-reduced microspore with $\mathbf{n}=$ ca. 72 chromosomes in a $2 \mathrm{n}=73$ plant (no. J79-223-2 from Maliotenam, Fig. 29). The occurrence of unreduced pollen grains has been reported from Carex by Tanaka (1941b) and from Eleocharis by Strandhede (1965b).

Figs. 15-22. 15-20: Meiosis and pollen mitosis in Carex salina. 15, metaphase II in no. J79-390 $l$ (Saint-Fulgence). A ring quadrivalent is visible ( $\mathrm{r}$ ), and many bivalents are dumb-bell shaped. 16 , late anaphase II in no. $J 79-390-1$ (Saint-Fulgence). One large chromosome (bivalent or quadrivalent) is lagging. 17 , late anaphase II in no. $578-64-I$ (îlets-Jérémie) showing univalents lagging in both cells. 18, telophase II in no. J78-64-1 (Îlets-Jérémie) with no laggards in the spindles. Laggards have reached one of the nuclei. 19, late prophase of first pollen mitosis in no. J79 $390-l$ (Saint-Fulgence) $\mathrm{n}=37$. One large chromosome is nucleolar. 20, metaphase of first pollen mitosis in no. $J 81-248-2$ (Manitounuk) $\mathrm{n}=38$. There are two large chromosomes (1), one being the largest $(\mathrm{L})$. The three degenerating nuclei are not visible here. 21-22: Pre-meiotic mitosis and meiosis in Carex recta. 21, metaphase of pre-meiotic mitosis in no. J79-216-1 (ilets-Caribou) $2 \mathrm{n}=$ 73. There are four large chromosomes (1), one pair being the largest (L). One nucleolus belongs to another cell $(\mathrm{n})$. 22, late metaphase $\mathrm{I}$ in no. $J 78-198-1$ (Montmagny) $2 \mathrm{n}=73(33 \mathrm{II}+1 \mathrm{I}+2 \mathrm{III})$. There are three large bivalents (1), one being the largest (L). One trivalent is a heteromorphic chain $(\mathrm{h})$, the other is a frying-pan type (f). The univalent is a small rounded body (u). Bar scales= $10 \mu \mathrm{m}$. 


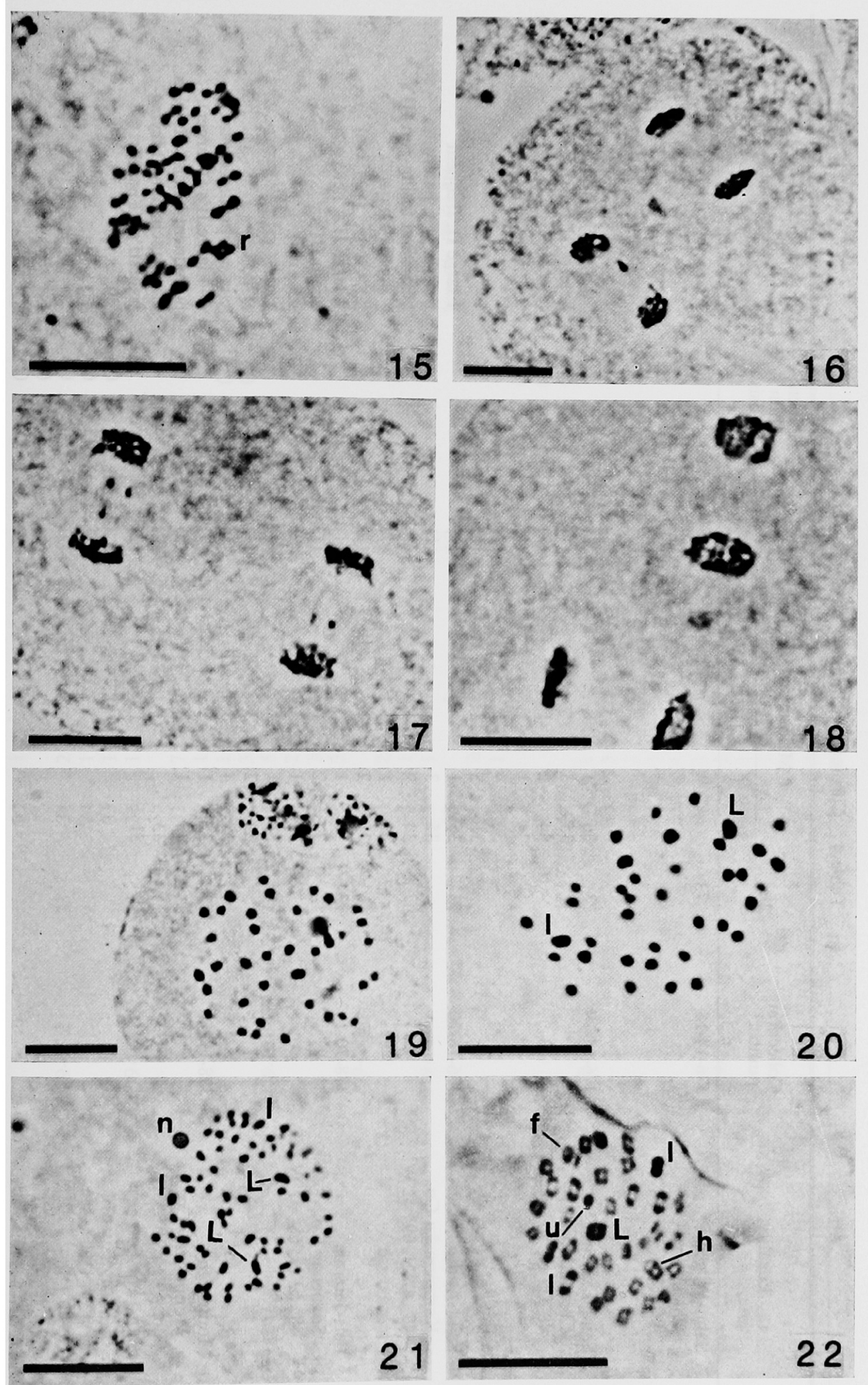




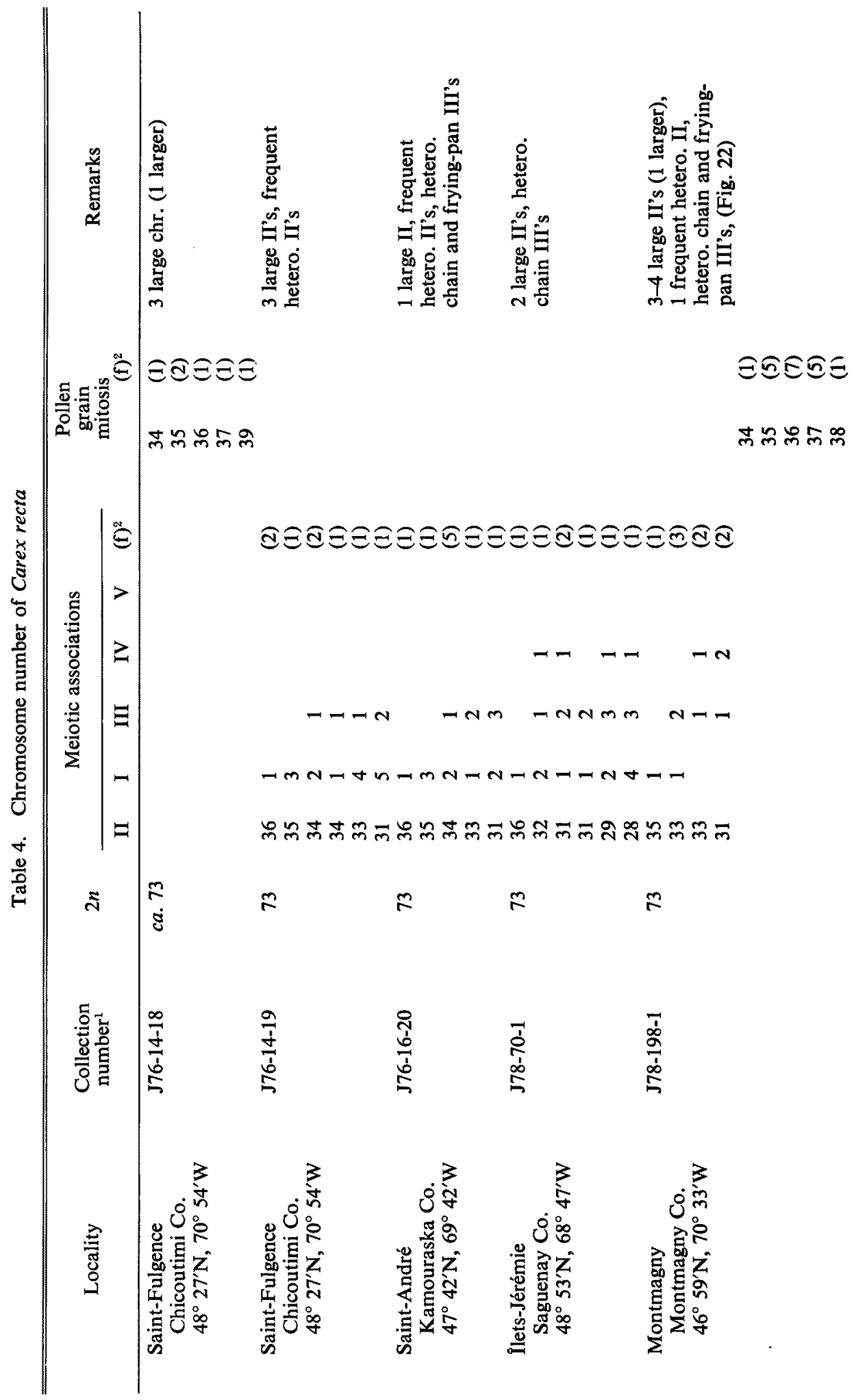




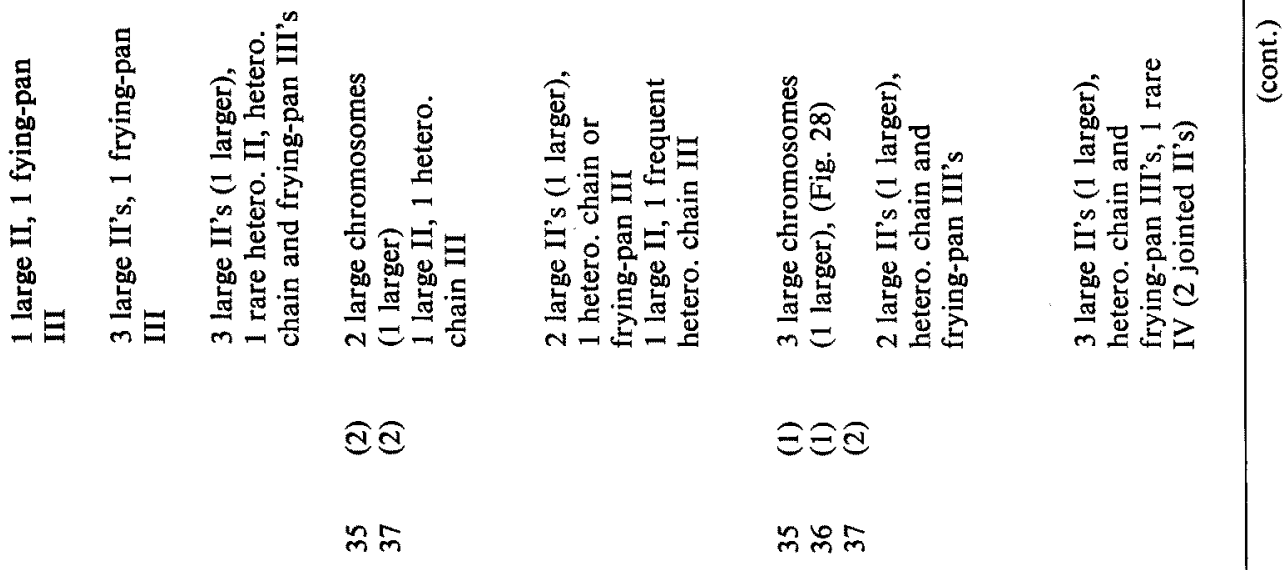

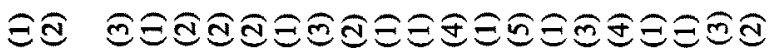

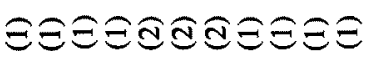

$4 \rightarrow-n \rightarrow n-n-n-4-6$

$-4-\pi-4 N 4$

$-\mathrm{NH}-\mathrm{N}-\mathrm{N}-\mathrm{N}-$

$\rightarrow m N-m-N-m m$

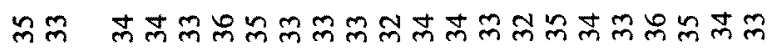

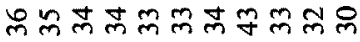

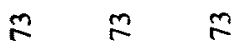

$m \quad m$

$m$

$m$

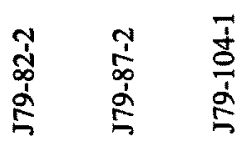

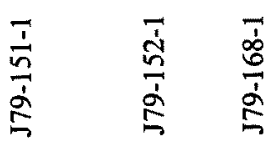

$\frac{\pi}{2} \frac{1}{2}$

$\begin{array}{ll}\frac{7}{1} & \frac{7}{\pi} \\ \frac{1}{2} & \frac{1}{5}\end{array}$

군

웅 y

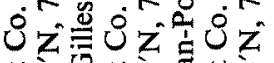

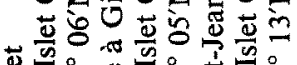

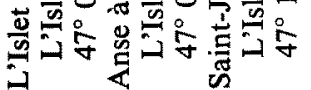

है है हु

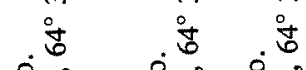

نz $\quad \dot{0} z \& \dot{0} z$

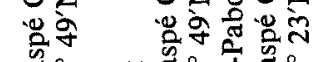

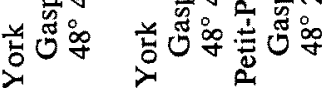

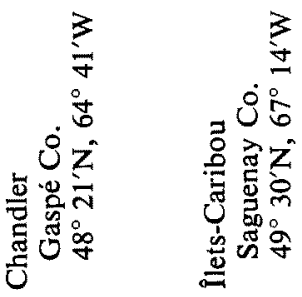




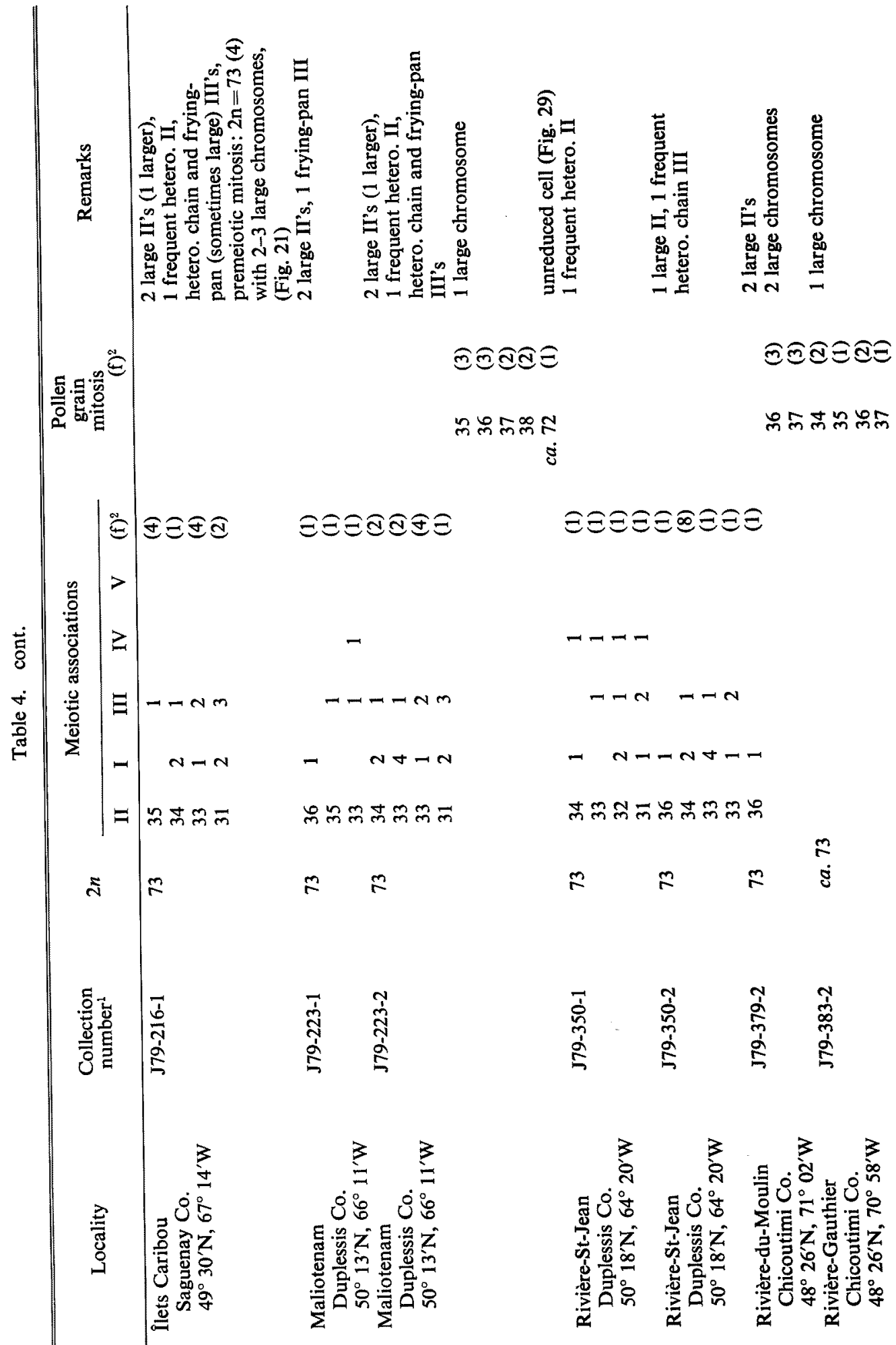



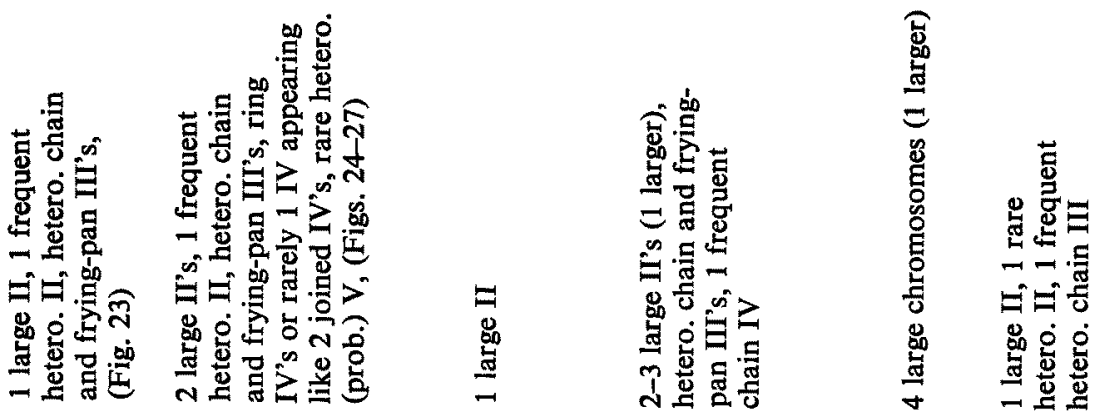

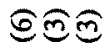

ரீn்

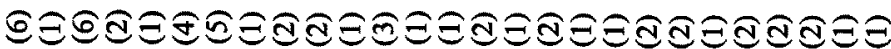

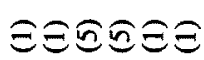

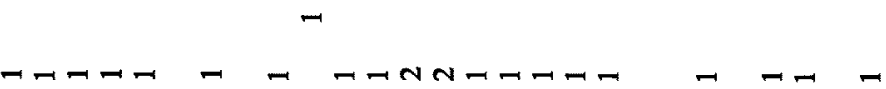

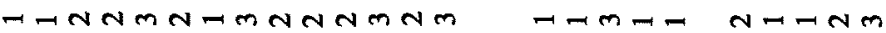

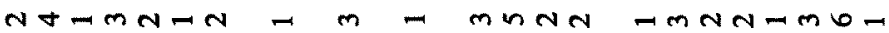

$N-N-4$

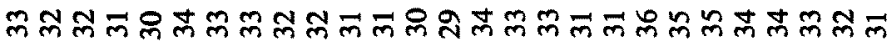

ㅁํำ

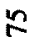

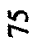

$\approx$

$\leftarrow$

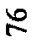

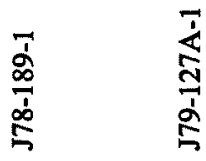

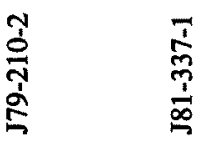

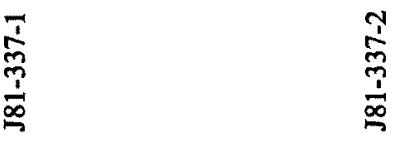
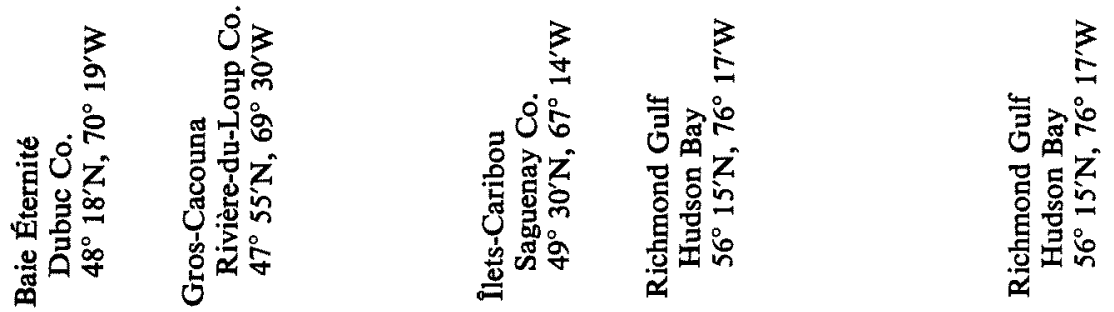


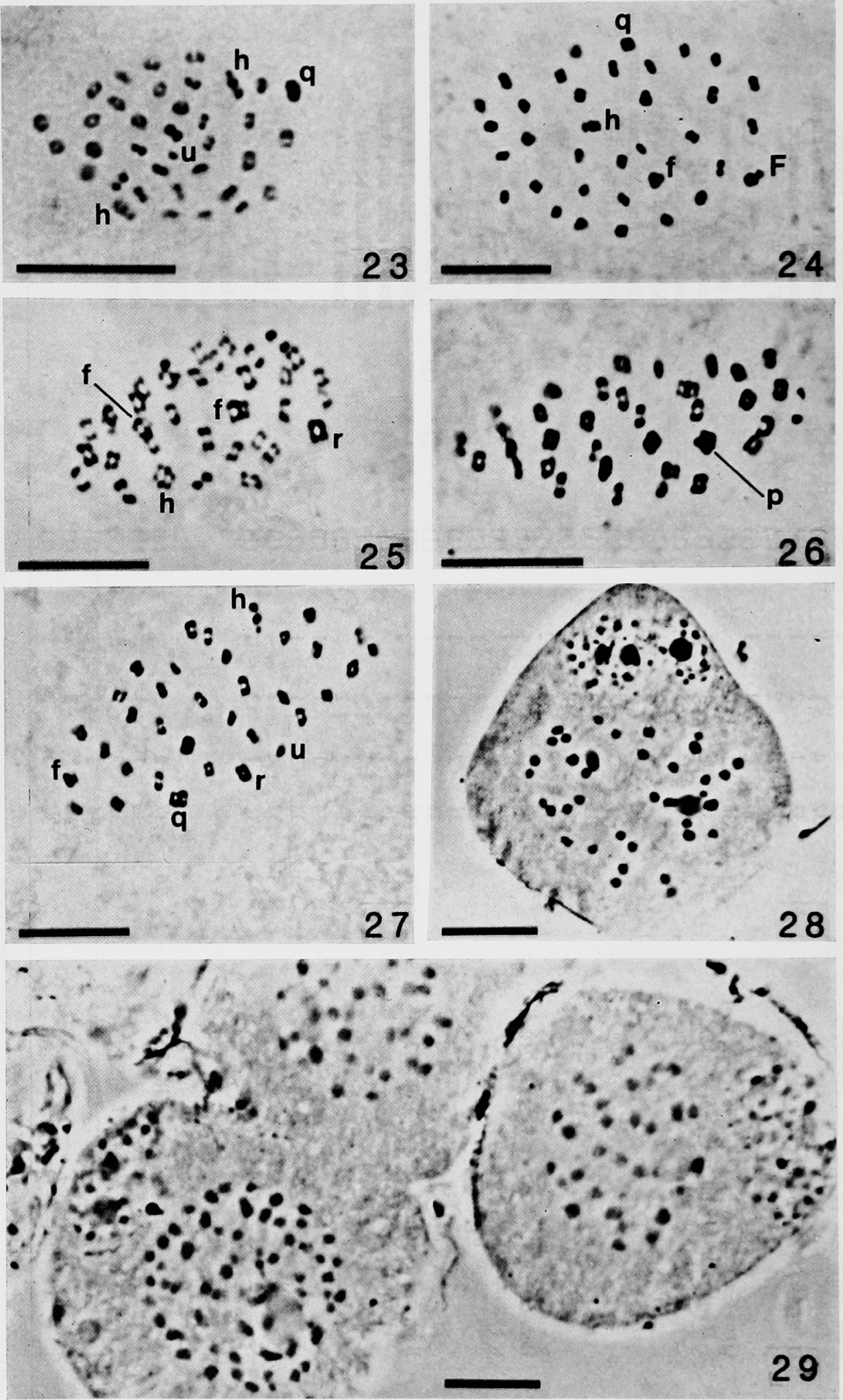


Faulkner (1972) had postulated their occurrence to explain the triploid nature of an individual of Carex nigra which he interpreted as the result of the fertilization of a reduced megaspore by an unreduced microspore. We do not know exactly which mechanism could explain the origin of such an unreduced pollen grain. Instead of three degenerating microspores in the pollen grain as usual, only two degenerated and the other two seemed to be united, giving the doubled chromosome number in a restitution nucleus (Fig 29). This triad must have resulted from the fusion of two nuclei during the second meiotic division. Restitution nuclei at meiosis have been observed in other plants (e.g. Ononis, Morisset 1967).

The $2 n=73$ and 75 cytotypes of $C$. recta had a similar meiotic behaviour (Table 4). Both had comparable mean numbers of bivalents, univalents and trivalents, but differences were met with quadrivalents. For the $2 n=73$ cytotype the frequency of occurrence of a quadrivalent was $18 \%$, while it was much higher $(85 \%)$ for the $2 n=75$ plants. The $2 n=76$ cytotype, represented by two plants only, seemed to differ cytologically from the other two. The mean number of bivalents was greater, univalents did not exceed two, trivalents were sometimes missing, and one quadrivalent was seen most of the times.

No clear geographical pattern emerged from the distribution of the two southern cytotypes, the $2 n=73$ one being far more frequent ( 20 plants) than the $2 n=75$ one ( 3 plants). The two plants with $2 \mathrm{n}=76$ came from Hudson Bay. No apparent morphological differences seem to exist between plants of the three cytotypes. Variation is great within $C$. recta, and extreme plants are found in all cytotypes.

\section{Discussion and conclusion}

\section{Chromosome numbers}

The three species of the $C$. salina complex differ from each other both by their chromosome numbers and by their meiotic behaviour. The whole complex forms

Figs. 23-29. Meiosis and pollen mitosis in Carex recta. 23, metaphase I in no. J78-189-I (Baie Éternité) $2 n=75(32 I I+1 I+2 I I I+1 I V)$. One chain trivalent is clearly heteromorphic (h at top). 24 , metaphase I in no. $J 79-127 A-1$ (Gros-Cacouna) $2 \mathrm{n}=75(31 \mathrm{II}+3 \mathrm{III}+1 \mathrm{IV})$. Three types of trivalents are visible; one is a heteromorphic chain $(\mathrm{h})$, the other two are frying-pan types: one is larger $(\mathrm{F})$ and the other is smaller (f). 25, early anaphase $I$ in no. $J 79-127 A-1$ (Gros-Cacouna) $2 \mathrm{n}=75$ (31II+ 3III+1IV). Bivalents and trivalents are beginning to divide equationally. Bivalents adopt square shapes with one chromatid in each corner. Two trivalents are frying-pan types (f), the other one is a heteromorphic chain (h). The quadrivalent appears as a closed ring (r). 26, early anaphase I in no. $J 79-127 A-1$ (Gros-Cacouna) $2 n=75(32 \mathrm{II}+2 \mathrm{III}+1 \mathrm{~V})$. Some bivalents have almost separated (see at extreme right). The pentavalent looks like a large heteromorphic body (p). 27, late metaphase $\mathrm{I}$ in no $579-127 A-1$ (Gros-Cacouna) $2 \mathrm{n}=75$ (30II + 1I+2III +2IV). Two types of trivalents are visible: one heteromorphic chain $(\mathrm{h})$. one frying-pan (f). Two types of quadrivalents are shown: one small ring $(r)$ and the other one which appears as two joined II's $(q) .28$, late prophase of first pollen mitosis in no. $J 79-168-1$ (Petit-Pabos) $n=37$. At least two large chromosomes are associated with the nucleole. The three degenerating nuclei are visible in the tapered part of the microspore. 29, late prophase of first pollen mitosis of two microspores of no. $J 79-223-2$ (Maliotenam) $n=36$ (right), $\mathrm{n}=c a .72$ (left). In the former, an unreduced pollen grain is present; the two degenerating nuclei are not clearly visible, but the approximate number of chromosomes of the favoured other two is evident. Bar scales $=10 \mu \mathrm{m}$; phase contrast except for Fig. 23. 
an aneuploid series with almost consecutive numbers from $2 n=73$ to $2 n=83$. Individual species within the complex have their own short aneuploid series which barely overlap. For $C$. subspathacea, five nearly consecutive numbers $(2 n=78,80$, $81,82$ and 83$)$ were found, and shorter series in $C$. salina $(2 \mathrm{n}=77,78$ and 79$)$ and in $C$. recta $(2 \mathrm{n}=73,75$ and 76$)$. For $C$. salina, $2 \mathrm{n}=77$ was more frequent than the other two numbers, and for $C$. recta $2 n=73$ was the most frequent number, but no number stood out as markedly more frequent in $C$. subspathacea. There was some indication of a differential geographical pattern in the distribution of the five cytotypes of C. subspathacea (Fig. 2), but no such pattern emerged for the other two species.

We encountered different chromosome numbers neither within the same population nor in the same individual. That is different from the situation reported by Schmid (1982) for C. flava in Switzerland. As the propagation of these populations is mainly by rhizomes, it is possible that each of the populations studied cytologically was actually one or a few extensive clones. In some cases, different chromosome numbers occurred in nearby populations from the same general locality (e.g. $2 n=77$ and 78 in $C$. salina from Îlets-Jérémie; $2 n=77$ and 79 from Île aux Coudres; $2 n=73$ and 75 in C. recta from îlets-Caribou).

\section{Chromosome size}

According to Davies (1956) and Faulkner (1972) who studied the related Section Phacocystis, chromosomes were not readily classifiable in size classes. However, Faulkner (1972) noted that some larger bivalents could be observed in some species, and that numbers of large bivalents tended to decrease with increasing chromosome numbers. However, this generalization does not hold for other species in Section Phacocystis such as $C$. lenticularis which has a high chromosome number $(2 \mathrm{n}=88)$ but a distinctly larger bivalent as metaphase I (Cayouette unpubl.).

In the species of the Carex salina complex, chromosomes could not be classified according to size, but 1-3 larger bivalents were almost always observed. These larger bivalents could not always be seen easily in every cell. In contrast with the situation in Section Phacocystis (Faulkner 1972), about the same numbers of large bivalents $(2-3)$ occurred from the lowest cytotype $(2 n=73)$ in $C$. recta to the highest one $(2 \mathrm{n}=83)$ in $C$. subspathacea, Within each species, numbers of large bivalents remained the same even when chromosome numbers increased.

These larger bivalents were frequently associated with the nucleolus when seen at diakinesis, interphase and prophase of the first pollen mitosis. Studying meiosis of Scirpus lacustris L., Tanaka (1938) observed large chromosomes which were always situated near the nucleolus or attached to it. Therefore, these larger chromosomes were probably nucleolar chromosomes.

\section{Meiotic associations}

As shown in Tables 2-4, most of the cytotypes of the Carex taxa studied did not show a regular pairing at metaphase $I$. The occurrence of non-bivalent associations was the rule for $C$. salina and $C$. recta, and for two of the five cytotypes of $C$. subspathacea. 
The numerous meiotic associations listed in Tables $2-4$ do not easily lead to clear comparisons between cytotypes within and between species, mostly because pairing variation from cell to cell will blur any slight differences between cytotypes. In order to partly overcome this difficulty, pairing information for any given individual was synthetized in the following way. We worked out the simplest i.e. the most parsimonious common pattern of pairing affinities that could account for the various association patterns observed in the cells of an individual plant. Suppose, for instance, that there are four homologous chromosomes in a given plant. These can occur at metaphase I as a quadrivalent, as a trivalent plus a univalent, or as two bivalents, depending on initial pairing and subsequent chiasmata. Similarly, three homologous chromosomes can occur either as a trivalent or as a bivalent plus a univalent. Comparing the association patterns of the many mataphase I cells from a given plant, it was thus possible to deduce the pairing affinities which could give rise to all realized associations observed at meiosis in this plant. This maximum meiotic association for a given individual was designated its "Maximum Affinity Pairing" or MAP. A MAP formula was thus worked out for every plant from which at least nine cells had been analysed at metaphase I (see Cayouette and Morisset 1985, for more details).

MAP formulae are listed in Table 5. They are made up of a variable number of bivalents, trivalents, quadrivalents and once a pentavalent. Univalents which were actually observed in metaphase I cells were thus all considered to be derived from potential multivalents. Evidence that univalents could result from heteromorphic chain trivalents, was the frequent occurrence of heteromorphic bivalents with at least one univalent in the same cell (Figs. 11, 14). For some plants two MAP formulae are given because they were equally acceptable. Analysis of further cells would undoubtedly have permitted to discriminate between them.

With few exceptions, MAP formulae were not actually observed (Table 5). MAP's differed, of course, between cytotypes, but they frequently were the same for some individuals of a given cytotype within the same species. Even if MAP's differed within the same cytotype, numbers of trivalents were almost always the same, and were congruent with the maximum numbers actually observed (Table 5). This regularity indicated a relative homogeneity within a given cytotype. However,numbers of quadrivalents in MAP formulae were more variable within a given cytotype, e.g. for $2 \mathrm{n}=77$ salina.

MAP formulae were used to calculate an index of meiotic regularity that we called "euploidy index". This index is simply the ratio of the number of chromosomes in bivalents on the total number of chromosomes. The euploidy index is of course 1.0 for perfectly diploidized cytotypes such as C. subspathacea (J79-176-2, $2 n=80$ ) and lower than 1.0 for any plant with multivalents or univalents. This index was also calculated directly for each cell analyzed in metaphase I. The mean for each individual was computed and is called the "observed euploidy index" (Table 5).

These indexes allowed us to compare the different cytotypes of each species, or to compare the different species. The observed indexes of $C$. subspathacea were the highest of all the three species (0.933-1.0), those of C. salina were the lowest $(0.797-$ 


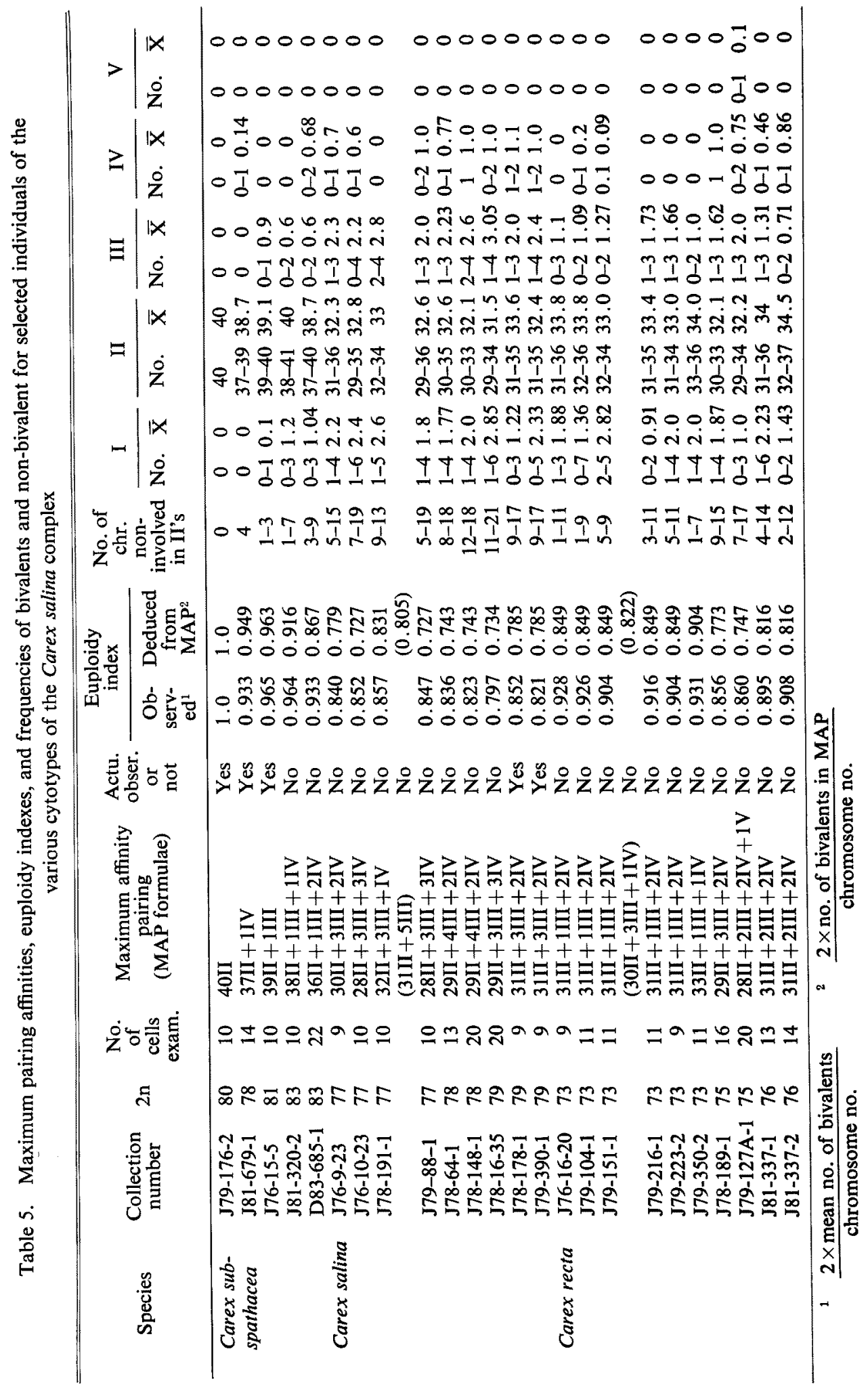


0.857), those of $C$. recta being intermediate $(0.856-0.931)$. There were also differences between cytotypes of the same species. The $2 n=77$ cytotype of $C$. salina had the highest indexes of the three cytotypes. The $2 n=73$ cytotype of $C$. recta was markedly the less "disturbed" cytotype of all the three $(0.904-0.931)$. The $2 \mathrm{n}=$ 75 cytotype had the lowest indexes $(0.856$ and 0.860$)$. Except for $C$. salina at $2 \mathrm{n}=$ 79 , all the indexes were rather uniform within a given cytotype.

Similar differences were observed from "MAP-deduced euploidy indexes" (Table 5). The $2 \mathrm{n}=83$ subspathacea is, for example, the most disturbed of all $(0.867-$ 0.916). Differences between the cytotypes of $C$. recta are well marked, the $2 \mathrm{n}=73$ one being the less disturbed cytotype, as it was the case from the "observed indexes". Such data provided by both indexes show, for instance, that C. recta $(2 n=73)$ is not a very disturbed "taxon", contrary to the opinion of Faulkner (1972) who considered European $C$. recta as a hybrid and removed it from the usual classification of the Cryptocarpae.

Table 5 also shows the variable numbers of bivalents and non-bivalents in different species, cytotypes and individuals. Numbers of univalents are the most variable, but their mean values are always lower than 3 . The cytotypes of $C$. subspathacea have the highest numbers of bivalents (38-40), the remaining two species showing a narrow range of mean numbers, between 32 and 34 . The mean values of trivalents are lower than 1 in cytotypes of $C$. subspathacea; they are ranging from 2 to 3 in C. salina, and from 1 to 2 in C. recta. The presence (or absence) of quadrivalents is diagnostic for some cytotypes or individuals. Within the cytotypes of $C$. salina, the $2 \mathrm{n}=79$ cytotype has the highest mean frequency of quadrivalents, thus suggesting a possible explanation for the differences between $2 n=77$ and 79 cytotypes in this species. The diagnostic feature of the $2 n=73$ cytotype of $C$. recta is certainly the rare occurrence of a quadrivalent.

\section{Origin of aneuploidy in the Carex salina complex}

Aneuploidy is commonly found at every level in the genus Carex: within the whole genus, within sections, within species group and within species. Explanations for the origin and causes of aneuploidy in Carex have been proposed by seveal workers (Heilborn 1924, 1939, Tanaka 1940a, 1949, Davies 1955, Faulkner 1972, Schmid 1982) and it seems that causes could differ with the group of Carex species studied. Faulkner (1972) suggested that aneuploidy must be primarily structural and caused by agmatoploidy, i.e. fission or fusion of chromosomes, with some possible chromosome rearrangements. On the other hand, Schmid (1982) claimed that quantitative aneuploidy, originating from duplication or deletion of whole chromosomes, seemed to be the most important factor in the Carex flava complex. It is difficult to test these alternative hypotheses because chromosomes of Carex are small and numerous in groups where aneuploidy is encountered.

In $C$. subspathacea, two cytotypes $(2 \mathrm{n}=80$ and $2 \mathrm{n}=82)$ had a perfectly regular meiosis. Artificial hybrids between these two cytotypes would be necessary to see whether this difference is due to fission or fusion, or to a "diploidized tetrasomy". Differences in chromosome size for one or two pairs would give relevant indications, but such differences if any are difficult to assess due to the small size of most chromosomes. 
The $2 n=81$ cytotype with one trivalent could be interpreted either as a trisomic from $2 n=80$, or as a hybrid between a parent with $2 n=80$ and another one with $2 n=82$. In the first case the trivalent would be homomorphous; in the latter case it would be heteromorphous if the difference between the putative parents $(2 n=80$ and 82 ) is indeed due to fission/fusion. The trivalent in the $2 n=81$ was often heteromorphic as shown in Fig. 6, and we therefore interpret this plant as an intraspecific hybrid, between parents of the two known euploid cytotypes of $2 n=80$ and 82 . These two cytotypes seem to have an allopatric distribution along the St. Lawrence River, and the $2 n=81$ plant was collected from an intermediate locality (Fig. 2); it is hypothesized that other individuals from the same locality should show all three numbers, but this remains to be cheked.

These results are quite similar to those reported by Tanaka (1949) for two aneuploid intraspecific hybrids between Carex oxyandra Kudo and C. gibba Wahl. (Table 6). These aneuploid hybrids were artificially produced by intraspecific crosses between euploid parents differing by one chromosome pair only. Tanaka's hybrids had one trivalent and one or a few univalents at meiosis. The trivalents, as seen at metaphase I in his Figs. 1-6, were all heteromorphic. Their MAP formulae and their euploidy indexes were computed (Table 6), and they are comparable with

Table 6. Meiotic associations in two artificial intraspecific hybrids made by

Tanaka (1949) between cytotypes of Carex oxyandra Kudo ( $9 \mathrm{II} \times 10 \mathrm{II})$ and of C. gibba Wahl. (17II $\times 18 \mathrm{II})$

\begin{tabular}{|c|c|c|c|c|c|c|c|c|}
\hline \multirow{3}{*}{ Species } & \multirow{2}{*}{\multicolumn{3}{|c|}{$\begin{array}{c}\text { Meiotic } \\
\text { associations } \\
\text { observed by } \\
\text { Tanaka }\end{array}$}} & \multirow{3}{*}{$\begin{array}{l}\text { Number } \\
\text { of cells } \\
\text { examined }\end{array}$} & \multirow{3}{*}{$\begin{array}{c}\text { Maximum } \\
\text { affinity } \\
\text { pairing } \\
\text { (MAP formulae) }\end{array}$} & \multirow{3}{*}{$\begin{array}{l}\text { Actually } \\
\text { observed } \\
\text { or not }\end{array}$} & \multicolumn{2}{|c|}{ Euploidy index } \\
\hline & & & & & & & $\begin{array}{l}\text { Deduced } \\
\text { from }\end{array}$ & Observed \\
\hline & II & I & III & & & & MAP & \\
\hline \multirow{3}{*}{$\begin{array}{c}\text { C. oxyandra } \\
(2 \mathrm{n}=19)\end{array}$} & 9 & 1 & & 52 & $8 \mathrm{II}+1 \mathrm{III}$ & Yes & 0.842 & 0.918 \\
\hline & 8 & 3 & & 11 & & & & \\
\hline & 8 & & 1 & 9 & & & & \\
\hline \multirow{3}{*}{$\begin{array}{l}\text { C. } g i b b a \\
\quad(2 \mathrm{n}=35)\end{array}$} & 17 & 1 & & 3 & $14 I I+1 I I I+1 I V$ & No & 0.800 & 0.915 \\
\hline & 16 & & 1 & 35 & & & & \\
\hline & 15 & 2 & 1 & 2 & & & & \\
\hline
\end{tabular}

those of the $2 n=81$ cytotype of $C$. subspathacea. However, the presence of a quadrivalent in the MAP formula of the $C$. gibba hybrid was hypothesized in order to explain the occurrence of two univalents in two cells $(15 I I+2 I+1 I I I)$, but Tanaka did not observe any quadrivalent in this hybrid (Table 6). If our interpretation is correct, the presence of one quadrivalent would show that the two parents of this hybrid also differed by one reciprocal translocation or by one fusion/fission. However, it is also possible that these two univalents could have resulted from one desynaptic bivalent.

The $2 \mathrm{n}=78$ cytotype of $C$. subpathacea from Ungava is quasi-euploid. The presence of one quadrivalent in a few cells is difficult to interpret. It could be the result of tetrasomy from an hypothetical $2 n=76$ cytotype. Another explanation might be heterozygosity for a reciprocal translocation, but then the frequency of the 
quadrivalent would be higher. In Greenland, the $2 \mathrm{n}=78$ cytotype of $C$. subspathacea appeared to be perfectly euploid (Jørgensen et al. 1958). Some examples of such individuals with one quadrivalent are known from $C$. nigra and $C$. acuta each at $2 \mathrm{n}=84$ (40II+IV), $\mathrm{n}=42 \mathrm{II}$ being more frequent (Faulkner 1972).

Concerning the $2 \mathrm{n}=83$ cytotype of $C$. subspathacea from Hudson Bay, trisomy and double-tetrasomy could explain its meiotic behaviour. In both cases trivalent and quadrivalents would be homomorphic. Homomorphy or heteromorphy of quadrivalents was not easy to observe and we could not verify it with complete accuracy. Trivalents however were frequently heteromorphic (Fig. 7) and so trisomy must be rejected as a sole explanation. The $2 n=83$ cytotype could equally have originated from intraspecific hybridization between parents with $2 n=82$ and 84 differing by one fusion/fission and by two reciprocal translocations such as in Tanaka's $C$. gibba discussed above. However, no plant of $C$. subspathacea has been found with $2 \mathrm{n}<83$.

On the other hand, interspecific hybridization between parents with chromosome numbers below and over $2 n=83$ could theoretically explain the origin of plants with $2 \mathrm{n}=83$. Most of the species related to $C$. subspathacea in northeastern North America (C. salina, recta, aquatilis and paleacea) have chromosome numbers lower than $2 n=83$. There are only two species of the Section Phacocystis with $2 n>83$, namely $C$. nigra $(2 \mathrm{n}=83-85$, unpubl.) and $C$. lenticularis Michx. ( $2 \mathrm{n}=88$, unpubl.). However, C. nigra has never been found in the Hudson Bay area, and a possible cross involving $C$. lenticularis is highly improbable owing to the morphology of $C$. subspathacea. A more complete sampling of this species and of related species from the Hudson Bay region would be necessary to solve this problem.

Contrary to $C$. subspathacea, $C$. salina and $C$. recta had no cytotype with a perfectly regular meiosis (Tables 3,4 ). Different cytotypes could have originated either from trisomy and tetrasomy in otherwise perfectly diploidized, hypothetical cytotypes, or from intra- or interspecific hybridization. Every multivalent in different combinations and in MAP formulae for the various cytotypes of those two species (Table 5) could be considered as a case of polysomy. However, this explanation must be rejected because most of the trivalents observed were heteromorphic as were some quadrivalents and the pentavalent in $2 n=75 \mathrm{C}$. recta.

Another possibility is to consider any trivalent as the result of a fusion/fission polymorphism, and quadrivalents as reciprocal translocation polymorphisms. The differences in chromosome numbers between cytotypes within one species would then be ascribed to fission and/or fusion of chromosomes. This is consistent with the fact that most multivalents in those species are heteromorphic. Fusion/fission does not appear to involve the large chromosomes in those species. Polymorphism within a population for a chromosome fission or fusion would necessarily bring about variation in chromosome numbers in that population. Unfortunately, too few individuals per population were studied to document the presence of such variation.

It should be finally mentioned that the origin of these cytotypes has been attributed to interspecific hybridization. A hybrid origin for $C$. recta was suggested by Faulkner $(1972,1973)$. He stated that Scottish individuals of $C$. recta, having 
chromosome numbers ranging from $2 \mathrm{n}=c a .73$ to $c a .75$, were interspecific hybrids between $C$. paleacea $(2 \mathrm{n}=72)$ and $C$. aquatilis $(2 \mathrm{n}=76)$. Norwegian plants of $C$. recta, having chromosome numbers averaging $2 \mathrm{n}=80$ would have $C$. paleacea for one parent and either C. nigra or C. acuta $(2 \mathrm{n}=84)$ for the other parent. Similar hypotheses were put forward for C. salina by Hjelmqvist and Nyholm (1947) and Hylander (1966), who suggested that $C$. salina had originated by interspecific hybridization between $C$. paleacea and $C$. subspathacea. These opinions cannot be fruitfully discussed without studying the meiosis of artificial interspecific hybrids between the species involved.

The explanation of the origin of aneuploidy in Carex salina and C. recta must thus remained open until much larger numbers of individuals are studied. Further works on this problem should attempt to study the meiosis in as many individuals as possible from few carefully chosen populations, and should involve artificial intraspecific hybrids between the various cytotypes.

\section{Abstract}

In northeastern North America, the Carex salina complex includes three related species growing on boreal or arctic salt marshes: C. subspathacea Wormsk., C. salina Wahl. s. str., and C. recta Boott. Chromosome studies (numbers and meiotic behaviour) were done on plants from the St. Lawernce River valley, Hudson Bay, and Hudson Strait. In 14 individuals of $C$. subspathacea, an aneuploid series was found with $2 \mathrm{n}=78,80,81,82$ and $83 ; 2 \mathrm{n}=81$ is a first record, and $2 \mathrm{n}=80$ and 82 are the only perfectly euploid cytotypes. In 22 individuals of $C$. salina $(2 \mathrm{n}=77,78$ and 79$)$ and 25 of $C$. recta $(2 n=73,75$ and 76$)$ no cytotype with a perfectly regular meiosis was found. The three different numbers of $C$. salina and $2 n=76$ in $C$. recta are new records for these species respectively. The high frequency of heteromorphic trivalents in these plants seems to indicate that aneuploidy is most likely the result of fission and/or fusion of chromosomes. A formula indicating the maximum affinity pairing (MAP formula) and two euploidy indexes were devised in order to compare aneuploid individuals, cytotypes, and species. These data showed that aneuploid cytotypes of $C$. subspathacea $(2 \mathrm{n}=78,81$ and 83$)$ and the $2 \mathrm{n}=73$ cytotype of $C$. recta are the least disturbed of all the cytotypes studied. The origin of the various cytotypes is discussed. One case of unreduced microspore in $C$. recta was found.

Key words: Carex, meiotic pairing, aneuploidy, agmatoploidy, trivalents.

\section{Résumé}

Dans le nord-est de l'Amérique du Nord, le complexe du Carex salina s. l. comprend trois espèces croissant dans les marais salés boréaux ou arctiques: $C$. subspapaวpy $\urcorner$ Wormsk., C. salina Wahl. s. str. et C. recta Boott. Les auteurs ont étudié les chromosomes (nombres et comportement méiotique) de plantes provenant de la vallée du Saint-Laurent, de la baie d'Hudson et du détroit d'Hudson. Les 14 indi- 
vidus de $C$. subspathacea forment une série anuploïde de $2 \mathrm{n}=78,80,81,82,83$, avec $2 \mathrm{n}=81$ comme nombre nouveau pour cette espèce, et $2 \mathrm{n}=80$ et 82 comme seuls cytotypes parfaitement euploïdes. Chez 22 individus de $C$. salina $(2 n=77,78,79)$ et 25 de $C$. recta $(2 \mathrm{n}=73,75,76)$ aucun des cytotypes n'est parfaitement euploïde. Les trois nombres du $C$. salina sont nouveaux ainsi que $2 n=76$ pour $C$. recta. La forte fréquence de trivalents hétéromorphes semble indiquer que l'aneuploïdie de ces plantes serait surtout causée par fission et/ou fusion de chromosomes (agamtoploïdie). En vue de comparer plus adéquatement les individus aneuploïdes entre eux (ainsi que les cytotypes et les espèces), une formule indiquant l'affinité maximale d'appariement a été élaborée ainsi que deux indices d'euploïdie. Ces données ont permis de déterminer que les cytotypes aneuploïdes de $C$. subspathacea $(2 \mathrm{n}=78,81,83)$ et celui à $2 \mathrm{n}=73$ de $C$. recta sont les moins perturbés de tous. L'origine des différents cytotypes est discutée. Un cas de non-réduction est signalé chez $C$. recta.

Mots clés: Carex, appariement méiotique, aneuploïdie, agmatoploïdie, trivalents.

\section{Acknowledgements}

We wish to thank governmental organisms who provided us with financial support during the course of this study. Scholarships were obtained by the first author from Natural Sciences and Engineering Research Council of Canada (N.S.E.R.C., Ottawa), from Fonds F.C.A.C. (Québec), and from Laval University. A N.S.E. R.C. grant (A-5702) to the second author is gratefully acknowledged. Logistical and financial supports were provided by the Centre d'Études nordiques (Laval University) for field work in Northern Québec. The first author is pleased to thank the staff of the Northern Québec Raglan Mine for his 1981 trip at Douglas Harbour, Ungava. We also thank the technicians and gardeners of the Department of Phytology (Laval University) for care of the cultivated plants. Occasional assistance in the field and in the garden was kindly provided by Martin Dubé, and cytological assistance by Janouk Murdock was greatly appreciated. We thank Jean Deshaye for the supply of one collection of C. subspathacea from Hudson Bay. The staff of the Louis-Marie Herbarium helped us in various ways. Guy Plante, and particularly Céline Dallaire printed the photographs; assistance for figures and maps was provided by Céline Dallaire and Ivan Grenier.

\section{Literature cited}

Boivin, B. 1979. Flora of the prairie provinces. Part 4. Monopsida. Phytologia, 43: 1-106. Reprinted in Provancheria (Mémoires de l'Herbier Louis-Marie, Université Laval, Québec), No. 5 .

Borgen, L. and Elven, R. 1983. Chromosome numbers of flowering plants from northern Norway and Svalbard. Nord. J. Bot. 3: 301-306.

Cayouette, J. and Morisset, P, 1985. Chromosome studies on natural hybrids between maritime species of Carex (sections Phacocystis and Cryptocarpae) in northeastern North America, and their taxonomic implications. Can. J. Bot. 63: 1975-1982.

- and - 1986. Chromosome studies on Carex paleacea Wahl., C. nigra (L.) Reichard, and C. aquatilis Wahl. in northeastern North America. Cytologia 51: 857-883.

Chater, A. O. 1980. Carex L. in Flora Europaea. Vol. 5. Ed. T. G. Tutin, V. H. Heywood, N. A. 
Burges, D. M. Moore, D. H. Valentine, S. M. Walters and D. A. Webb. Cambridge University Press, Cambridge. pp. 290-323.

Davies, E. W. 1955 . The cytogenetics of Carex flava and its allies. Watsonia 3: 129-137.

- 1956. Cytology, evolution and origin of the aneuploid series in the genus Carex. Hereditas 42: $349-365$.

Dietrich, W. 1967. Die Zytotaxonomie der Carex-Sektion Frigidae in Europa. Fed. Repert. 75: $1-42$.

Dumortier, B. C. J. 1827. Florula Belgica. Operis Majoris Prodromus Staminacia. Tornaci Nerviorum.

Dutilly, A. and Lepage, E. 1948. Coup d'oeil sur la flore subarctique du Québec de la baie James au lac Mistassini. Contr. Arct. Inst. Cath. Univ. Am. Washington, D.C. No. 1F.

-, Lepage, E. and Duman, M. 1958. Contribution à la flore des Îles (T.N.O.) et du versant oriental (Qué.) de la Baie James. Contr. Arct. Inst. Cath. Univ. Am. Washington, D. C. No. 9F.

Egorova, T. 1972. Caricum subgeneris Caricis partis Europeae URSS systema et synopsis. Novitates Systematicae Plantarum Vascularium 9: 64-95 (in Russian).

Engelskjön, T. 1970. Studies of the flora of Bear Island (Björnöya) I. Vascular plants. Astarte 3: p. 8. In Engelskjön, T. and H.-J. Schweiter.

- 1979. Chromosome numbers in vascular plants from Norway, including Svalbard. Op. Bot. Soc. Bot. Lund. 52: 1-38.

Faulkner, J. S. 1972. Chromosome studies on Carex section Acutae in north-west Europe. Bot. J. Linn. Soc. 65 : 271-301.

- 1973. Experimental hybridization of north-west European species in Carex section Acutae (Cyperaceae). Bot. J. Linn. Soc. 67: 233-253.

Fedorov, A. (ed.). 1969. Chromosome Numbers of Flowering Plants. By Z. Bolkhoskikh, V. Grif, T. Matvejeva, $O$. Zukharyeva. Leningrad.

Fernald, M. L. 1950. Gray's Manual of Botany. 8th ed. American Book Co., New York.

Fries, E. 1835. Corpus florarum provinciarum Sueciae, p. 191.

Gauthier, B. 1980. Les limites phytogéographiques du Saint-Laurent. Provancheria (Mémoires l'Herbier Louis-Marie, Université Laval, Québec). No. 11.

Gleason, H. A. 1952. The New Britton and Brown Illustrated Flora of the Northeastern United States and Adjacent Canada Vol. 1. New York Botanical Garden, Lancaster Press, Lancaster, Penna.

Goldblatt, P. (ed.). 1981. Index to Plant Chromosome Numbers 1975-1978. Monographs in Systematic Botany. Vol. 5.

Heilborn, O. 1924. Chromosome numbers and dimensions, species-formation and phylogeny in the genus Carex. Hereditas 5: 129-216.

- 1928. Chromosome studies in Cyperaceae. Hereditas 11: 182-192.

- 1939. Chromosome studies in Cyperaceae III-IV. Hereditas 25: 224-240.

Hjelmqvist, H. and Nyholm, E. 1947. Några anatomiska artkaraktärer inom Carex-gruppen distigmaticae. Bot. Not. 1947: 1-31.

Hultén, E. 1942. Flora of Alaska and Yukon Vol. 2. Monocotyledonae (Glumiflorae Spathiflorae). Lunds Univ. Arsskr. Adv. 38: 1-412.

- 1958. The Amphi-atlantic Plants and their Phytogeographical Connections. Almquist \& Wiksell, Stockholm.

- 1964. The circumpolar plants I. Vascular Cryptogams, Conifers, Monocotyledons. Almquist \& Wiksell, Stockholm.

Hylander, N. 1966. Nordisk Kärlväxtflora Vol. 2. Almqvist \& Wiksell, Stockholm.

Johnson, A. W. and Packer, J. G. 1968. Chromosome numbers in the flora of Ogotoruk Creek, N. W. Alaska. Bot. Not. 121 : 401-456.

Jørgensen, C. A., Sørensen, T. and Westergaard, M. 1958. The flowering plants of Greenland. A taxonomical and cytological survey. Biol. Skr. Dansk. Vidensk. Selsk. 9: 1-172.

Juel, H. O. 1900. Beiträge zur Kenntniss der Tetradentheilung. Jb. Wiss. Bot. 35: 626-659.

Krechetovich, V. 1935. Carex. In Flora U.R.S.S. III. Ed. V. Komarov. Izdatelstuo Akademii Nauk SSSR, Moscow and Leningrad. 
Kükenthal, G. 1909. Cyperaceae. Caricoideae. In A. Engler: Das Pflanzenreich 4 (20). Engelmann, Leipzig.

Lepage, E. 1956. Études sur quelques plantes américaines IV. Carex hybrides. Nat. Can. 83: 105-156. Reprinted in Contr. Arct. Inst. Cath. Univ. Am. Washington, D. C. No. 6F.

- 1957a. Études sur quelques plantes américaines VI. Nat. Can. 84: 89-103. Reprinted in Contr. Arct. Inst. Cath. Univ. Am. Washington. D. C. No. 8F.

- 1957b. Études sur quelques plantes américaines V. Nat. Can. 84: 37-62. Reprinted in Contr. Arct. Inst. Cath. Univ. Am. Washington, D. C. No. 7F.

- 1966. Aperçu floristique du secteur nord-est de l'Ontario. Nat. Can. 93: 207-246.

- 1976. Un Carex hybride et deux variétés nouvelles de Graminées. Nat. Can. 103: 387-390.

Löve, Á. 1970. Islenzk ferdaflóra. Reykjavik.

- and Löve, D. 1956. Cytotaxonomical conspectus of the Icelandic flora. Acta Horti Gothob. 20: $65-291$.

- and - 1975. Cytotaxonomical Atlas of the Arctic Flora. Cramer, Vaduz.

- and - 1981. Pages 845-851 in Löve, Á., IOPB chromosome number reports LXXIII. Taxon 30: 829-861.

-, - and Raymond, M. 1957. Cytotaxonomy of Carex Section Capillares. Can. J. Bot, 35: 715-761.

Mackenzie, K. K. 1935. Cariceae. North. Am. Flora 18: 1-478.

Moore, R. J. and Calder, J. A. 1964. Some chromosome numbers of Carex species of Canada and Alaska. Can. J. Bot. 42: 1387-1391.

Morisset, P. 1967. Cytological and taxonomic studies in Ononis spinosa L., O. repens L. and related species. Ph.D. Thesis. University of Cambridge.

- 1978. Chromosome numbers in Ononis L. series Vulgares Širj. Watsonia 12: 145-153.

Nelmes, E. 1952. Facts and speculations on phylogeny in the tribe Cariceae of the Cyperaceae. Kew Bull. 1951: 427-436.

Packer, J. G. and McPherson, G. D. 1973. Chromosome numbers in some vascular plants from northern Alaska. Can. J. Bot. 52: 1095-1099.

Payette, S. and Lepage, E. 1977. La flore vasculaire du Golfe de Richmond, Baie d'Hudson, Nouveau-Québec. Provancheria (Mémoires de l'Herbier Louis-Marie, Université Laval, Québec) No. 7.

Petrovsky, V. V. and Zhukova, P. G. 1983. Polyploids and diploids in the vascular flora of the Wrangel Island. Bot. Zh. 68 : 749-760 (in Russian).

Polunin, N. 1940. Botany of the Canadian eastern Arctic Part I: Pteridophyta and Spermatophyta. Natl Mus. Can. Bull. 92.

- 1948. Botany of the Canadian eastern Arctic Part III: Vegetation and Ecology. Natl. Mus. Can. Bull. 104.

Porsild, A. E. 1964. Illustrated flora of the Canadian Arctic archipelago. Natl. Mus. Can. Bull. 146. Second ed. revised.

Raymond, M. 1950. Les Cypéracées de l'île d'Anticosti: Carex et Kobresia. Can. J. Res., C. 28: $406-444$.

Schmid, B. 1982. Karyology and hybridization in the Carex flava complex in Switzerland. Fed. Repert. 93: 23-59.

Scoggan, H. J. 1978. The flora of Canada. Part 2. Pteridophyta, Gymnospermae, Monocotyledoneae. National Museums of Canada, Ottawa, p. 93-545.

Snow, R. 1963. Alcoholic hydrochloric acid-carmine as a stain for chromosome in squash preparations. Stain Technol. 38: 9-13.

Standley, L. A. 1983. A clarification of the status of Carex crinita and C. gynandra (Cyperaceae). Rhodora 85: 229-241.

Stout, A. B. 1913. The individuality of the chromosomes and their serial arrangement in Carex aquatilis. Arch. Zellforsh. 9: 114-140.

Strandhede, S.-O. 1965a. Chromosome studies in Eleocharis, subser. Palustres. I. Meiosis in some forms with 15 chromosomes. Hereditas 53: 47-62.

- 1965b. Chromosome studies in Eleocharis, subser. Palustres II. Pollen mitosis with special 
reference to some strains with 15 chromosomes, and formation of secondarily unreduced pollen grains. Heriditas 53: 374-388.

Sylvén, N. 1963. Det Skandinaviska flora-områdets Carices distigmaticae. Op. Bot. Soc. Bot. Lund 8 (2): 1-161.

Tanaka, N. 1937. Chromosomes of Scirpus lacustris L. Jap. Genet. 13: 254.

- 1938. Chromosome studies in Cyperaceae II. Scirpus lacustris L. Cytologia 8: 515-520.

- 1939a. Cytological studies in the genus Carex. A collective review. Jap. J. Genet. 15: 96104.

- 1939b. Chromosome studies in Cyperaceae IV. Chromosome number of Carex species. Cytologia 10: 51-58.

- 1940a. Chromosome studies in Cyperaceae VIII. Meiosis in diploid and tetraploid forms of Carex siderosticta Hance. Cỳtologia 11: 282-310.

- 1940b. Chromosome studies in Cyperaceae IX. Structural hybridity observed in meiosis of Carex lanceolata Boott. Bot. Mag. (Tokyo) 54: 378-388.

- 1940c. Chromosome studies in Cyperaceae X. Aneuploid plants of Carex multifolia Ohwi. Bot. Mag. (Tokyo) 54: 438-446.

- 1941a. Chromosome studies in Cyperaceae XI. Meiosis in Carex duvaliana. Jap. J. Bot. 11: 213-219.

- 1941b. Chromosome studies in Cyperaceae XIII. Aneuploid plants of Carex podogyna Franch. and Sav., with special reference to an abnormal pollen. Bot. Mag. (Tokyo) 55: 181-186.

- 1948. The problem of aneuploidy. (Chromosome studies in Cyperaceae, with special reference to the problem of aneuploidy). Biol. Contrib. in Japan 4: 1-327 (not seen).

- 1949. Chromosome studies in the genus Carex, with special reference to aneuploid and polyploid. Cytologia 15: 15-29.

Wahl,'H. A. 1940. Chromosome numbers and meiosis in the genus Carex. Am. J. Bot. 27: $458-470$.

Whitkus, R. 1981. Chromosome numbers of some northern New Jersey Carices. Rhodora 83: $461-464$.

Yurtsev, B. A. and Zhukova, P. G. 1978. The cytotaxonomical survey of the monocots of the easternmost Chukchi Peninsula. Bot. Zh. 63: 1132-1144 (in Russian).

Zhukova, P. G. and Petrovsky, V. V. 1980. Chromosome numbers and taxonomy of some species of the Anyui Mts. Bot. Zh. 65: 651-659 (in Russian).

- and Tikhonova, A. D. 1971. Chromosome numbers of certain plant species indigenous to the Chukotskiy Province I. Bot. Zh. 56: 868-875 (in Russian). 